Chapter 9

\title{
Microbial Degradation of Lignocellulosic Biomass
}

\author{
Wagner Rodrigo de Souza \\ Additional information is available at the end of the chapter \\ http://dx.doi.org/10.5772/54325
}

\section{Introduction}

The search for renewable sources of energy requires a worldwide effort in order to decrease the harmful effects of global climate change, as well as to satisfy the future energy demands. In this context, biofuels are emerging as a new source of energy derived from biomass. The production of biofuels could decrease effectively the impact of pollutants in the atmosphere, in addition to assisting in the management for tons of biomass waste. Biomass (plant matter) can be referred to "traditional biomass", which is used in inefficient ways such as the highly pollutant primitive cooking stoves (wood), and "modern biomass" that refers to biomass produced in a sustainable way and used for electricity generation, heat production and transportation of liquid fuels [1]. In addition to these definitions, The International Energy Agency (IEA) defines biomass as any plant matter that could be used directly as fuel or converted into fuels, electricity or heat. Therefore, in order to provide useful management of biomass, it is clear that one needs to learn how to extract energy from plants.

Plant cells are mainly composed by lignocellulosic material, which includes cellulose, hemicellulose and lignin (lignocellulosic complex). The hydrolysis of lignocellulose to glucose is a major bottleneck in cellulosic biofuel production processes [2]. In nature, microorganisms, especially fungi, are able to degrade the plant cell wall through a set of acting synergistically enzymes. This phenomenon leads to glucose being released in a free form, which can enter the metabolism of the microorganism, providing its energy. A great challenge is to modify the architecture of the plant cell walls and/or the ability of the microorganisms to degrade it, by modifying their genomes. For instance, researchers can generate genetically engineered microorganisms able to degrade efficiently the polymers in the plant cells, producing sugars monomers that can be fermented directly by yeasts, generating ethanol. This chapter will describe the composition of plant cell walls and how microorganisms cope with the lignocellulosic material. The main focus will be on fungi cell wall degrading enzymes (CWDEs) and their genetic regulation. The aim of this chapter is to guide scientists in order to genetically 
improve microorganisms that can be able to efficiently degrade the plant biomass. Also, new strains could be great producers of CWDEs, providing enzymatic cocktails that can be introduced commercially. Finally, the future perspectives will demonstrate how far we are from cellulosic ethanol and other biomass-derived chemical compounds, regarding to research of microorganisms.

\section{Plant cell wall polysaccharides and lignin}

Plant cell wall [6] polysaccharides are the most abundant organic compounds found in nature. These compounds consist mainly of polysaccharides such as cellulose, hemicelluloses and pectin, as well as the phenolic polymer lignin. Together, the polysaccharides and lignin provide high complexity and rigidity to the plant cell wall. Cellulose, the major constituent of plant cell wall consists of $\beta-1,4$ linked D-glucose units that form linear polymeric chains of about 8000-12 000 glucose units. In its crystalline form, cellulose consists of chains that are packed together by hydrogen bonds to form highly insoluble structures, called microfibrils. In addition to the crystalline structure, cellulose contains amorphous regions within the microfibrils (noncrystalline structure) [3].

Hemicelluloses are heterogeneous polysaccharides consisted by different units of sugars, being the second most abundant polysaccharides in plant cell wall. Hemicelluloses are usually classified according to the main residues of sugars present in the backbone of the structural polymer. Xylan, the most abundant hemicellulose polymer in cereals and hardwood, is composed by B-1,4-linked D-xylose units in the main backbone, and can be substituted by different side groups such as D-galactose, L-arabinose, glucuronic acid, acetyl, feruloyl, and p-coumaroyl residues [3]. Another two major hemicelluloses in plant cell wall are galacto(gluco)mannans, which consist of a backbone of 1 -1,4-linked D-mannose (mannans) and D-glucose (glucomannans) residues with D-galactose side chains, and xyloglucans that consist of a B-1,4-linked D-glucose backbone substituted by D-xylose [3]. Moreover, in xyloglucan polymer, L-arabinose and D-galactose residues can be attached to the xylose residues, and L-fucose can be attached to galactose residues. The diversity of side groups that can be attached to the main backbone of xyloglucans confers to this polymers high structural complexity and variability [4]. Figure 1 represents schematic views of the three major hemicellloses.

Pectins are another family of plant cell wall heteropolysaccharides, containing a backbone of $\alpha$-1,4-linked D-galacturonic acid. The polymers usually contain two different types of regions. The so-called "smooth" region of pectins contains residues of D-galacturonic acids that can be methylated or acetylated. In the other region, referred as "hairy" region, the backbone of D-galacturonic acids residues is interrupted by $\alpha$-1,2-linked L-rhamnose residues. In the hairy region, long side chains of L-arabinose and D-galactose residues can be attached to the rhamnose residues [5]. Figure 2 depicts a schematic representation of the hairy region of pectins. 
A.

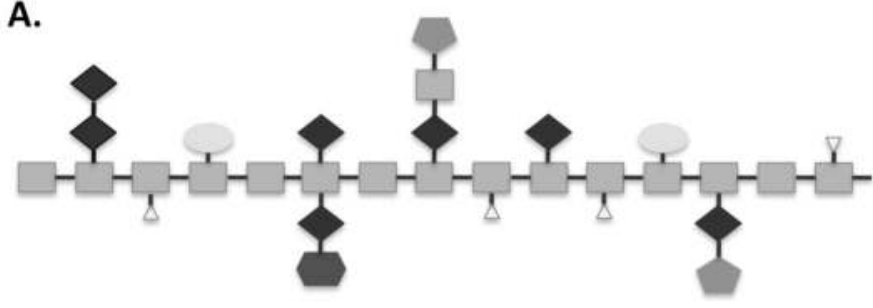

xylose
arabinose
glucuronic acid

galactose

ferulic acid

$\triangle$ acetyl group

B.

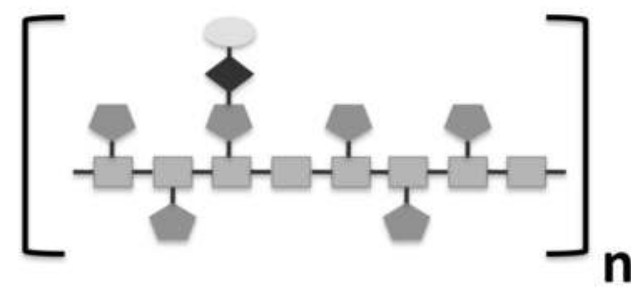

glucose

xylose

galactose

fucose
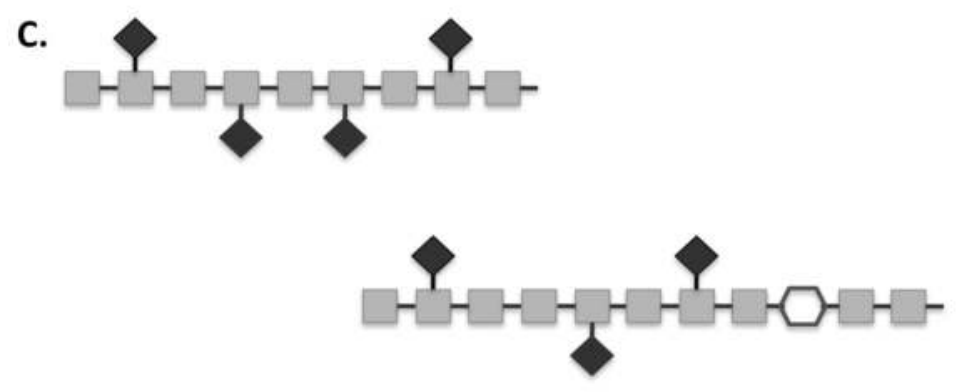

Figure 1. Schematic representation of the three major hemicellulose structures. A. Xylan. B. Xyloglucan. C. Galactomannan (upper left) and Galactoglucomannan (lower right).

Lignin is a phenolic polymer that confers strength to plant cell wall. Lignin is a highly insoluble complex branched polymer of substituted phenylpropane units, which are joined together by ether and carbon-carbon linkages, forming an extensive cross-linked network within the cell wall. The cross-linking between the different polymers described above con- 
fers the complexity and rigidity of the plant cell wall, which is responsible for the protection of plant cell as a whole. In addition to offer protection against mechanical stress and osmotic lysis, the plant cell wall is an effective barrier against pathogens, including many microorganisms. However, during the course of evolution some microorganisms, in order to survive, developed efficient strategies to degrade plant cell wall components, mainly the polysaccharides [6].

Plant cell wall degradation mechanisms are pivotal for the lifestyle of many microorganisms, once they should be able to degrade the plant polymers to acquire nutrients from plants. For instance, saprophytic fungi inhabit dead organic materials like decaying wood and leaves. In order to take energy from these materials, these fungi need to produce enzymes capable of degrading the majority of plant cell wall polysaccharides present in the biomass. The main mechanism through which fungi and other microorganisms degrade plant biomass consists of production and secretion of enzymes acting synergistically in the plant cell wall, releasing monomers that can be used by the microorganism as chemical energy. The next section will discuss mechanisms of cell wall degrading enzymes (CWDE) production by fungi, the most important producers of carbohydrate-active enzymes.

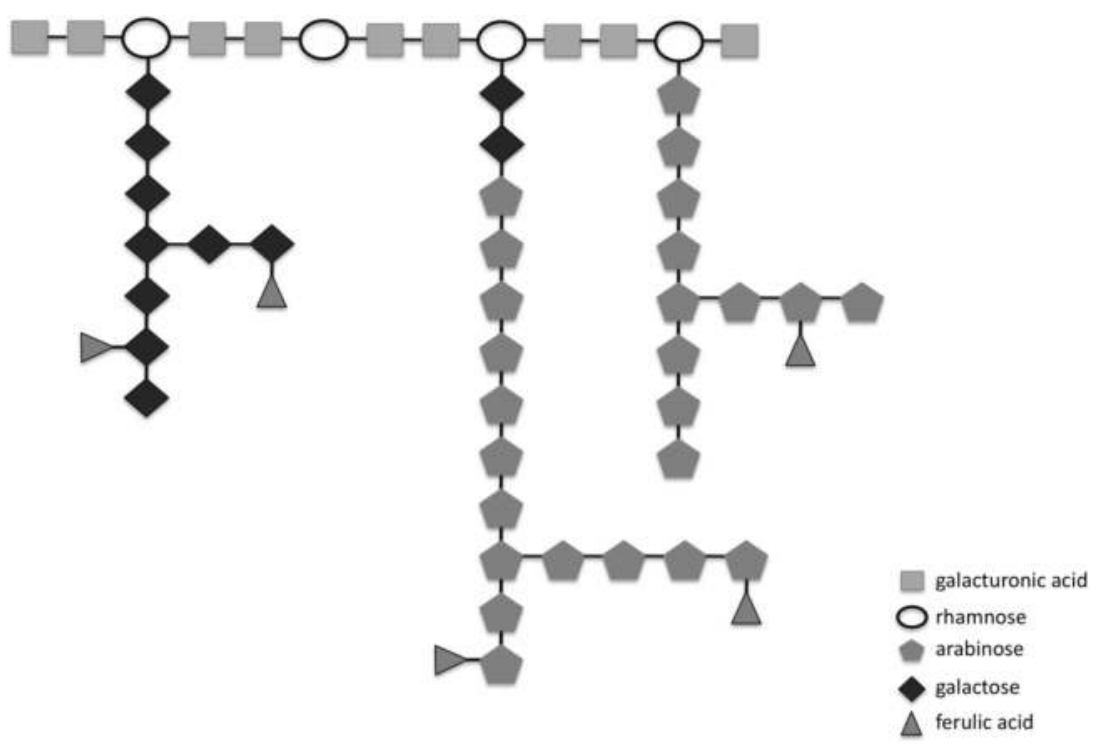

Figure 2. Schematic view of the hairy region of pectin.

\section{Microbial degradation of plant cell wall polysaccharides}

In order to survive, microorganisms developed, during the course of evolution, physiological mechanisms to cope with a variety of environmental factors. The acquirement of nu- 
trients represents a challenge for all living organisms, especially for microorganisms. Saprophytism, one of the most common lifestyle of microorganisms, involves living in dead or decaying organic matter, mainly composed by plant biomass. In this context, microorganisms developed cellular mechanisms in order to take energy from plant biomass, and one of this mechanisms involves the production and secretion of carbohydrate-active enzymes. These enzymes degrade the plant cell wall, releasing sugars monomers that can be used as substrates for the metabolism of the microorganism. The microbial use of plant biomass is pivotal for life on Earth, because it is responsible for large portions of carbon flux in the biosphere. In addition, plant cell wall-degrading enzymes (CWDEs) have a broad range of industrial applications, such as within the food and feed industry and for sustainable production of many chemicals and fuels.

The capacity to degrade lignocellulose is mainly distributed among fungi and bacteria. Cellulolytic bacteria can be found in different genus such as Clostridium, Ruminococcus, Caldicellulosiruptor, Butyrivibrio, Acetivibrio, Cellulomonas, Erwinia, Thermobifida, Fibrobacter, Cytophaga, and Sporocytophaga. Bacterial degradation of cellulolytic material is more restrict to biomass containing low amounts of lignin, once bacteria are poor producers of lignanases. Plant biomass produced in aquatic environment, containing little amounts of lignin, is typically degraded by bacteria, which are better adapted for an aquatic environment than fungi [7]. Cellulolytic bacteria can also be found in digestive tracts of herbivore animals [8]. Fungal cellulose utilization is distributed within the entire kingdom, from the protist-like Chytridomycetes to the advanced Basidiomycetes.

Concerning to lignin degradation, many white-rot basidiomycetes and some actinomycetes are able to produce lignin-degrading enzymes, especially peroxidases. For instance, Phanerochaete chrysosporium and Phlebia radiata are well known producers of extracellular peroxidases [9], as well as Coriolus tersicolor, which was shown to produce the intracellular haem peroxidase upon the induction by phenolic compounds [10]. A white-rot basidiomycete, Rigidoporous lignosus, is known to secrete two oxidative enzymes, laccase and Mn peroxidase, responsible for solubilizing the lignin in a synergistic way [11].

The fungi Hypocrea jecorina (Trichoderma reesei) is the most important organism used in cellulase production $[12,13]$ and it has been the focus of cellulases research for over 50 years. Degradation of cellulose is performed by cellulases, a high specific class of enzymes able to degrade the cellulose glycosidic bonds. The filamentous fungi Aspergillus niger is known to produce a wide range of hemicellulose-degrading enzymes and it has been used for many industrial applications. As discussed above, hemicellulose is a complex class of polysaccharides composed by different units of sugars. In order to degrade hemicellulose, the organism should be able to produce a large set of enzymes (hemicellulases), acting in a synergistic way to hydrolyze such complex substrate. Therefore, the ascomycetes T. reesei and A. niger are considered the most important microorganisms for cellulase/hemicellulase production, and constitute the source of these enzymes for industrial applications, including the production of biofuels from plant biomass.

The plant cell wall-degrading machinery of aerobic and anaerobic microorganisms differs significantly, regarding to its macromolecular organization. The cellulase/hemicellulase 
apparatus of anaerobic bacteria is frequently assembled into a large multienzyme complex, named cellulosomes [14, 15]. This complex contains enzymes with a variety of activities such as polysaccharide lyases, carbohydrate esterases and glycoside hydrolases [16-18]. Basically, the catalytic components of the cellulosomes include a structure named dockerins, which are noncatalytic modules that bind to cohesin modules, located in a large noncatalytic protein acting as scaffold [15]. The protein-protein interaction between dockerins and cohesins allows the integration of the hydrolytic enzymes into the complex $[19,20]$. It has been demostrated that scaffoldins are also responsible for the anchoring of the whole complex onto crystalline cellulose, through a noncatalytic carbohydratebinding module (CBM) [21]. The main studies concerning cellulosomes are being focused on anaerobic bacteria, especially from Clostridium species, but a range of other anaerobic bacteria and fungi were shown to produce cellulosomal systems. These include anaerobic bacteria such as Acetivibrio cellulolyticus, Bacteroides cellulosolvens, Ruminococcus albus, Ruminococcus flavefaciens, and the anaerobic fungi of the genera Neocalimastix, Pyromices and Orpinomyces [14, 15]. Cellulosome-based complexes design and construction is a promising approach for the improvement of hydrolytic activity systems. Cellulosomes able to integrate fungal and bacterial enzymes from nonaggregating systems could be generated to increase hydrolytic activities and consequently the biomass saccharification [22]. In addition, genetic manipulations could be used in order to introduce genes responsible for the synthesis of cellulosome into microorganisms able to ferment simple sugars but that do not have a functional plant cell wall-degrading machinery [23]. Alternatively, microorganisms naturally synthesizing cellulosomes could be engineered to increase their capacity to produce ethanol from lignocellulose [15]. Recently, using the architeture of cellulosomes as template, self-assembling protein complexes were successfully designed and constructed. These protein complexes were termed xylanosomes, and were designed specifically for hemicellulose hydrolysis, but demonstrated synergy with cellulases, suggesting a possible use of these nanostructures in cellulose hydrolysis as well [24].

\section{Ethanol production from the fermentable feedstock from lignocellulosic biomass}

Fermentative production of ethanol is largely performed nowadays through the use of starch or sucrose provided by agricultural crops such as wheat, corn or sugarcane. In Brazil, for instance, the ethanol production through yeast fermentation of substrates from sugarcane is a well-known and consolidated process. However, the improvement of fermentative processes towards utilization of lower-value substrates such as lignocellulosic residues is emerging as a valuable approach for reducing the production cost and consequently increasing the use of ethanol as biofuel. In sugarcane mills, for instance, a large quantity of sugarcane bagasse, which is a great source of lignocellulosic residue, is produced as a by-product of the industrial process. The sugarcane bagasse can be used as a lower-value substrate to produce the so-called second generation ethanol, in other words the ethanol generated from lignocellulosic material. The conversion of lignocellulose to 
ethanol requires challenging biological processes that includes: (i) delignification in order to release free cellulose and hemicellulose from the lignocellulosic material; (ii) depolymerization of the carbohydrates polymers from the cellulose and hemicellulose to generate free sugars; and (iii) fermentation of mixed hexose and pentose sugars to finally produce ethanol [25]. Glucose presents approximately $60 \%$ of the total sugars available in cellulosic biomass. The yeast Saccharomices cerevisiae is the most important microorganism able to ferment glucose (hexose), generating ethanol [26]. However, the presence of pentose sugars such as xylose and arabinose represents a challenge for the fermentation of these sugars in lignocellulosic biomass, once $S$. cerevisiae is not able to efficiently ferment C5 sugars. The naturally occurring microorganisms able to ferment C5 sugars include Pichia stipitis, Candida shehatae, and Pachysolen tannophilus [27]. From these microorganisms, the yeast $P$. stipitis has the highest ability to perform xylose fermentation, producing ethanol under low aeration rates. It appears that ethanol yields and productivity from xylose fermentation by $P$. stipitis are significantly lower than glucose fermentation by S. cerevisiae [28]. Therefore, genetic improvement of yeasts is a valuable tool to obtain strains able to ferment pentoses, hexoses and, in addition, produce ethanol with a high yield and a high ethanol tolerance as well. Genetically engineered organisms with C5 fermenting capabilities already include S. cerevisiae, Escherichia coli, Zymomonas mobilis and Candida utilis [28-31]. Studies on fungi degradation of lignocellulosic material could yield promising candidate genes that could be subsequently used in engineering strategies for improved cellulosic biofuel production in these yeast strains.

In summary, many microorganisms are able to produce and secrete hemicellulolytic enzymes, but fungi are pointed as the most important microorganisms concerning the biomass degradation. The significance of secreted enzymes in the life of these organisms and the biotechnological importance of filamentous fungi and their enzymes prompted an interest towards understanding the mechanisms of expression and regulation of the extracellular enzymes, as well as the characterization of the transcription factors involved. The next sections of this chapter will discuss the fungal enzyme sets for lignocellulosic degradation and the gene expression regulation of these enzymes.

\section{Fungal enzyme sets for lignocellulosic degradation}

Fungi play a central role in the degradation of plant biomass, producing an extensive array of carbohydrate-active enzymes responsible for polysaccharide degradation. The enzyme sets for plant cell wall degradation differ between many fungal species, and our understanding about fungal diversity with respect to degradation of plant matter is essential for the improvement of new strains and the development of enzymatic cocktails for industrial applications.

Carbohydrate-active enzymes are usually classified in different families, based on amino acid sequence of the related catalytic module. An extensive and detailed database presenting these hydrolytic enzymes can be found at www.cazy.org (CAZymes, Carbohydrate- 
Active EnZymes) [32]. The fungal carbohydrate-active enzymes commonly (but not always) present a carbohydrate-binding module (CBM), which promotes the association of the enzyme with the substrate. A review on fungal enzymes related to plant biomass degradation describes that such enzymes are assigned to at least 35 glycoside hydrolase (GH) families, three carbohydrate esterase (CE) families, and six polysaccharide lyase (PL) families [33]. Although the classification of CWDEs into families facilitates our view about a specific enzyme, the activities of these enzymes are quite complicated to classify, because some families can contain several enzymatic activities. This is especially important because CAZymes usually act in a synergistic way, complementing the substrate specificity of each other, in order to degrade complex polysaccharide matrices. For instance, GH5 comprises many catalytic activities, such as endoglucanases, exoglucanases and endomannanases [34]. This section will describe the fungal enzymatic set required for the main polysaccharides present in the plant biomass: cellulose, hemicellulose and pectin. A brief description of enzymes required for lignin degradation will be depicted. Because most of the research in cellulase/ hemicellulase field is performed using the fungi T. reesei and A. niger, the focus of our discussion about CWDEs will be conducted based on these microorganisms, although some aspects related to other fungal species could be mentioned to demonstrate the diversity of carbohydrate-active enzymes.

\section{Cellulose degradation}

Cellulose, a polysaccharide consisted of linear $\beta$-1,4-linked D-glucopyranose chains, requires three classes of enzymes for its degradation: $\beta$-1,4-endoglucanases (EGL), exoglucanases/cellobiohydrolases (CBH), and $\beta$-glucosidase (BGL). The endoglucanases cleave cellulose chains internally mainly from the amorphous region, releasing units to be degraded by CBHs and/or BGLs. The cellobiohydrolases cleave celobiose units (the cellulose-derived disaccahride) from the end of the polysaccharide chains [6]. Finally, $\beta$-glucosidases hydrolise cellobiose to glucose, the monomeric readily metabolisable carbon source for fungi [35]. These three classes of enzymes need to act synergistically and sequentially in order to degrade completely the cellulose matrix. After endo- and exo-cleaving (performed by EGLs and CBHs, respectively), the BGLs degrade the remaining oligosaccharides to glucose. A schematic view of cellulose degradation is depicted in the Figure 3.

The most efficient cellulose-degrading fungi is Trichoderma reesei. The highly efficient degradation of cellulose by $T$. reesei is mainly due to the highly effectiveness of cellulases acting synergistically in this specie, although $T$. reesei does not have the biggest number of cellulases in the fungi kingdom [36]. The T. reesei has five characterized EGLs, two highly expressed CBHs and two characterized BGLs, the latter being expressed at low levels $[37,38]$ reviewed in [33]. In addition to being expressed at very low levels in T. reesei, the BGLs are strongly subjected to product inhibition [39]. These features reduce the utilization of T. reesei for in vitro saccharification of cellulose substrates and, in industrial applications, cellulase mixtures from T. reesei are often supplemented with BGLs from Aspergilli, which are highly expressed and tolerant to glucose inhibition [33]. 


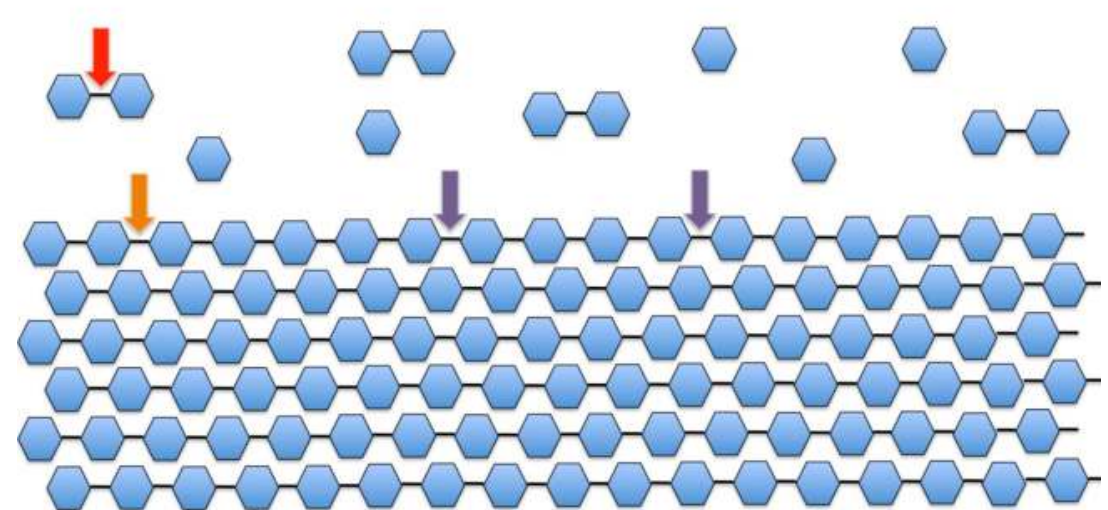

Glucose

$\beta$-Glucosidase

Cellobiohydrolase

Cellobiose

Endoglucanase

Figure 3. Schematic view of cellulose degradation. Endoglucanases hydrolise cellulose bonds internally, while cellobiohydrolases cleave celobiose units from the ends of the polysaccharide chains. The released cellobiose units (disaccharide) are finally hydrolyzed by $\beta$-glucosidases, releasing glucose, the main carbon source readily metabolisable by fungi.

\section{Hemicellulose degradation}

Hemicellulose is a complex polysaccharide matrix composed of different residues branched in three kinds of backbones, named xylan, xyloglucan and mannan. The complexity of hemicellulose requires a concerted action of endo-enzymes cleaving internally the main chain, exo-enzymes releasing monomeric sugars, and accessory enzymes cleaving the side chains of the polymers or associated oligosaccharides, leading to the release of various mono- and disaccharides depending on hemicellulose type.

Xylan, a polymer composed by $\beta-1,4$-linked D-xylose units, is degraded through the action of B-1,4-endoxylanase, which cleaves the xylan backbone into smaller oligosaccharides, and ß 1 -1,4-xylosidase, which cleaves the oligosaccharides into xylose. Fungal B-1,4-endoxylanase are classified as GH10 or GH11 [40], differing from each other in substrate specificty [41]. Endoxylanases belonging to family GH10 usually have broader substrate specificity than endoxylanases from family GH11 [33]. GH10 endoxylanases are known to degrade xylan backbones with a high degree of substitutions and smaller xylo-oligosaccharides in addition to degrade linear chains of 1,4-linked D-xylose residues. Thus, GH10 endoxylanases are necessary to degrade completely substituted xylans [42]. ß-Xylosidases are highly specific for 
small unsubstituted xylose olygosaccharides and they are important for the complete degradation of xylan. Some $\beta$-xylosidases have been shown transxylosylation activity, suggesting a role for these enzymes in the synthesis of specific oligosaccharides [43, 44].

Xyloglucan consists of B-1,4-linked D-glucose backbone substituted mainly by D-xylose and therefore requires endoglucanases (xyloglucanases) and B-glucosidases action in order to be degraded. Some endoglucanases are specific for the substituted xyloglucan backbone, and they are not able to hydrolise cellulose [45]. Xyloglucan-active endoglucanases have specific modes of action. For instance, a xyloglucanase from $T$. reesei cleaves at branched glucose residues, whereas the GH12 xyloglucanase from A. niger prefers xylogluco-oligosaccharides containing more than six glucose residues with at least one nonbranched glucose residue [46]-[47].

Mannans, also referred to galacto(gluco)mannans, consist of a backbone of B-1,4-linked Dmannose (mannans) and D-glucose (glucomannans) residues with D-galactose side chains. The degradation of this type of hemicellulose is performed by the action of ß-endomannanases (ß-mannanases) and $ß$-mannosidases, commonly expressed by aspergilli [48]. The $ß$ mannanases cleave the backbone of galacto(gluco)mannans, releasing mannooligosaccharides. Several structural features in the polymer determine the ability of B-mannanases to hydrolise the mannan backbone, such as the ratio of glucose to mannose and the number and distribution of substituents on the backbone [49]. It has been shown that $B$-mannanase is most active on galactomannans with a low substitution of the backbone [50], and the presence of galactose residues on the mannan backbone significantly prevents B-mannanase activity [51]. The main products of $\$$-mannanase activity on mannan are mannobiose and mannotriose. B-Mannosidases act on the nonreducing ends of mannooligosaccharides, releasing mannose. As shown by substrate specificity studies, B-Mannosidase is able to completely release terminal mannose residues when one or more adjacent unsubstituted mannose residues are present [52].

The complete degradation of hemicellulose is only achieved after release of all substitutions present on the main backbone. The high degree of substitution in the hemicellulose polymers requires the action of various accessory enzymes able to release all these substitutions from the polysaccharide. At least nine different enzyme activities distributed along $12 \mathrm{GH}$ and 4 CE families are required to completely degrade the hemicellulose substituents [33].

Arabinose is one of the most common sugar residues in hemicellulose and is present in arabinose-substituted xyloglucan and (arabino-)xylan. The release of arabinose from the polymer is performed by $\alpha$-arabinofuranosidases and arabinoxylan arabinofuranohydrolases. $\alpha$ Arabinofuranosidases are mainly found in GH 51 and 54 families, and the differences in the substrate specificity between these enzymes could be exemplified by two arabinofuranosidases of $A$. niger, AbfA and AbfB. AbfA (GH 51) releases L-arabinose from arabinan and sugar beet pulp, while AbfB (GH 54) also releases L-arabinose from xylan [48]. The arabinoxylan arabinofuranohydrolases act in the L-arabinose residues of arabinoxylan, specifically against the $\alpha$-1,2- or $\alpha-1,3-$ linkages [53]. Moreover, arabinoxylan arabinofuranohydrolases appear to be sensitive to the substitutions of adjacent D-xylose residues. AxhA, an arabinox- 
ylan arabinofuranohydrolase from $A$. niger, is not able to release arabinobiose from xylan or substitued L-arabinose from D-xylose residues adjacent to D-glucuronic acid residues [54].

Another type of substituent present in hemicellulose is D-xylose. Hydrolases responsible for the release of D-xylose residues from the xyloglucan backbone are referred to $\alpha$-xylosidases. These enzymes can differ with respect to the type of glycoside they can hydrolize. For instance, $\alpha$-xylosidase II (AxhII) from Aspergillus flavus hydrolyzes xyloglucan oligosaccharides and AxhIII is most active on $p$-nitrophenyl $\alpha$-L-xylose residues and does not hydrolyze xyloglucan $[55,56]$.

There are many other possible substituents in hemicellulose, such as L-fucose, $\alpha$-linked Dgalactose, D-glucuronic acid, acetyl group and $p$-coumaric and ferulic acids (Figure 1). A list containing the respective fungal accessory enzyme responsible for the release of each of these residues is shown in Table 1. An overview of fungal enzymatic complex for hemicellulose degradation is shown in Figure 4.

\begin{tabular}{ccc}
\hline Hemicellulose polymer & Residue released & Enzyme \\
\hline Xyloglucan/xylan & L-arabinose & a-arabinofuranosidases \\
\hline Xyloglucan & arabinoxylan arabinofuranohydrolases \\
\hline Xyloglucan & D-xylose & a-xylosidases \\
\hline Xylan/galactomannans & L-fucose & a-fucosidases \\
\hline Xylan & D-galactose & a-galactosidases \\
\hline Xylan & D-glucuronic acid & a-glucuronidases \\
\hline Xylan & acetyl group & acetyl xylan esterases \\
\hline Xylan & p-coumaric acid & p-coumaroyl esterases \\
\hline
\end{tabular}

Table 1. Fungal accessory enzymes for the cleavage of hemicellulose-derived residues.

\section{Pectin degradation}

Pectins are composed of a main backbone of $\alpha$-1,4-linked D-galacturonic acid, and consist of two regions: the "smooth" region and the "hairy" region. The "smooth" region contains residues of D-galacturonic acids that can be methylated or acetylated, while in the "hairy" region, the backbone of D-galacturonic acids residues is interrupted by $\alpha$-1,2-linked Lrhamnose residues. Moreover, in the hairy region, long side chains of L-arabinose and Dgalactose residues can be attached to the rhamnose residues (Figure 2). As observed for cellulose and hemicellulose, degradation of pectins also requires a set of hydrolytic enzymes to degrade completely the polymer. Glycoside hydrolases (GHs) and polysaccharide lyases (PLs) are the two classes of hydrolytic enzymes required for pectin backbone degradation. 
The GHs involved in pectin backbone degradation include endo- and exo-polygalacturonases, which cleave the backbone of smooth regions, while the intricate hairy regions are further degraded by endo- and exo-rhamnogalacturonases, xylogalacturonases, $\alpha$ rhamnosidases, unsaturated glucuronyl hydrolases, and unsaturated rhamnogalacturonan hydrolases [33]. Endo- and exo-polygalacturonases are able to cleave $\alpha$-1,4-glycosidic bonds of $\alpha$-galacturonic acids. Rhamnogalacturonases cleave $\alpha-1,2$-glycosidic bonds between Dgalacturonic acid and L-rhamnose residues in the hairy region of the pectin backbone [57]. An endo-xylogalacturonase from Aspergillus tubingensis has been shown to cleave the xylose-substituted galacturonic acid backbone [58]. The other GHs required for the degradation of main chain of pectin, $\alpha$-rhamnosidases, unsaturated glucuronyl hydrolases, and unsaturated rhamnogalacturonan hydrolases, are not well-characterized biochemically [33].

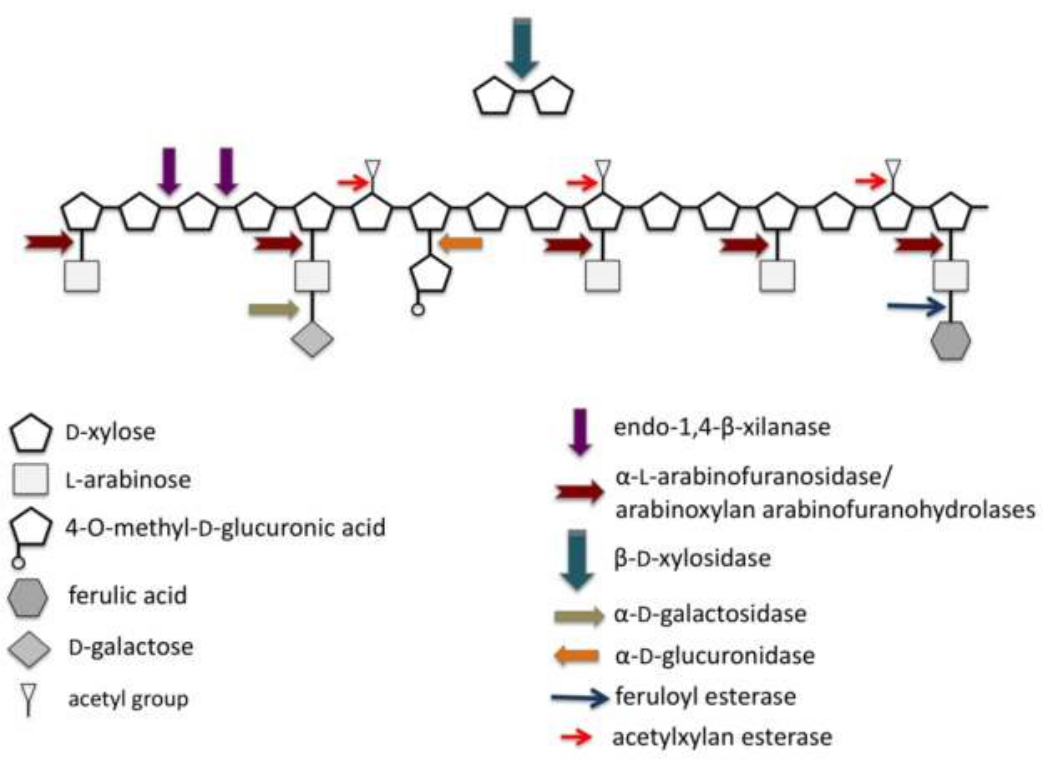

Figure 4. Schematic view on a hemicellulolytic system, degradation of arabinoxylan is depicted. The arrows represent each enzyme active for a determined substrate.

The fungal PLs pectin and pectate lyases hydrolyze $\alpha$-1,4-linked D-galacturonic acid residues in the smooth regions of pectin backbone [59]. Pectin lyases have preference for substrates with a high degree of methylesterification, whereas pectate lyases prefer substrates with a low degree of esterification. Moreover, pectate lyases require $\mathrm{Ca}^{2+}$ ions for catalysis while pectin lyases lack such ion requirement to catalysis [60]. The PL rhamnogalacturonan lyase cleaves within the hairy region of pectin and appears to be structurally different from pectin and pectate lyases. As presented by nailing reviews $[33,48]$, the pectin structures xylogalacturonan and rhamnogalacturonan require a repertoire of accessory enzymes to re- 
move the side chains, providing access for the main-chain pectinolytic enzymes. The accessory enzymes endoarabinanases, exoarabinanases, $\beta$-endogalactanases, and several esterases are specific for pectin degradation, while $\alpha$-arabinofuranosidases, $\beta$-galactosidases, and $\beta$-xylosidases are also required for hemicellulose degradation.

\section{Lignin degradation}

Lignin, a highly insoluble complex branched polymer of substituted phenylpropane units joined by carbon-carbon and ether linkages, provides an extensive cross-linked network within the cell wall, and it is known to increase the strength and recalcitrance of the plant cell wall. Microbial lignin degradation is often complicated, once the microbe needs to cope with three major challenges related to lignin structure: (i) enzymatic system to degrade the lignin polymer needs to be essentially extracellular, because lignin is a large polymer, (ii) the mechanism of enzymatic degradation should be oxidative and not hydrolytic, since the lignin structure comprises carbon-carbon and ether bonds, and (iii) lignin stereochemistry is irregular, requiring enzymes with less specificity than hydrolytic enzymes required for cellulose/hemicellulose degradation [61]. The most well characterized enzymes able to degrade the lignin polymer are lignin peroxidase (LiP), laccase (Lac), manganese peroxidase ( $\mathrm{MnP}$ ), versatile peroxidase, and $\mathrm{H}_{2} \mathrm{O}_{2}$-generating enzymes such as glyoxal oxidase (GLOX) and aryl alcohol oxidase (AAO).

Lignin and manganese peroxidases ( $\mathrm{LiP}$ and $\mathrm{MnP}$, respectively) catalyse a variety of oxidative reactions dependent on $\mathrm{H}_{2} \mathrm{O}_{2}$. LiP oxidizes non-phenolic units of lignin (mainly $\mathrm{C} \alpha-\mathrm{C} \beta$ bonds) by removing one electron and creating cation radicals that decompose chemically [62]. MnPs differ significantly from LiPs, once they cannot oxidize directly non-phenolic lignin-related structures [63]. In order to oxidize non-phenolic lignin-related components, the oxidizing power of MnPs is transferred to $\mathrm{Mn}^{3+}$, a product of the MnP reaction: $2 \mathrm{Mn}(\mathrm{II})+$ $2 \mathrm{H}^{+}+\mathrm{H}_{2} \mathrm{O}_{2} \rightarrow 2 \mathrm{Mn}(\mathrm{III})+2 \mathrm{H}_{2} \mathrm{O}$ [64]. In this way, $\mathrm{Mn}^{3+}$ diffuses into the lignified cell wall, attacking it from the inside [63].

Laccases oxidize phenolic compounds and reduce molecular oxygen to water. Lac catalyses the formation of phenoxyl radicals and their unspecific reactions, leading finally to C $\alpha$-hydroxyl oxidation to ketone, alkyl-aryl cleavage, demethoxylation and $\mathrm{C} \alpha-\mathrm{C} \beta$ cleavage in phenolic substructures [61]. Versatile peroxidases (VPs) are able to oxidize phenolic and non-phenolic aromatic compounds, as well as $\mathrm{Mn}^{2+}[64]$.

In order to degrade lignin, microbes require sources of extracellular $\mathrm{H}_{2} \mathrm{O}_{2}$, to support the oxidative turnover of LiPs and MnPs responsible for ligninolysis. The hydrogen peroxide is provided by extracellular oxidases that reduce molecular oxygen to $\mathrm{H}_{2} \mathrm{O}_{2}$, with the synergistic oxidation of a cosubstrate. The most well characterized extracellular $\mathrm{H}_{2} \mathrm{O}_{2}$-generating enzymes are glyoxal oxidase (GLOX) and aryl alcohol oxidase (AAO).

Most studies on enzymatic lignin degradation rely on white-rot fungi, which can mineralise lignin to $\mathrm{CO}_{2}$ and $\mathrm{H}_{2} \mathrm{O}$ in pure cultures $[65,66]$. Among these fungi are Phanero- 
chaete chrysosporium, Ceriporiopsis subvermispora, Phlebia subserialis, and Pleurotus ostreatus, which are able to metabolize the lignin in a variety of lignocellulosic biomass [62, 67, 68]. In addition, other species of fungi, such as Postia placenta (a brown-rot fungus), and some bacteria (such as Azospirillum lipoferum and Marinomonas mediterranea), are able to metabolize lignin. The saprotrophic homobasidiomycete Pycnoporus cinnabarinus is recognized by its high lignocellulolytic potential [69] overproducing high redox potential laccase, and a variety of studies have been performed in order to increase the ability of this specie to produce laccases for biotechnological applications, including heterologous expression in other species such as $A$. niger [70, 71, 72]. In addition, white-rot fungi such as Cyathus cinnabarinus and Cyathus bulleri demonstrated potential to degrade lignin [73, 74].

In summary, microbial degradation of lignocellulosic material requires a concerted action of a variety of enzymes arranged in an enzymatic complex, depending on the biomass to be degraded. The gene expression, production and secretion of plant cell wall-degrading enzymes demand energy from the microbial cells and therefore the overall process is highly regulated. There is an intense cross-talk in induction of expression of the genes encoding different classes of enzymes. The control of the regulation of CWDEs production could be the key for the development of new microbial strains that efficiently produce and secrete CWDEs. The regulation of genes encoding polysaccharide-degrading enzymes will be the subject of the next section of this chapter.

\section{Regulation of cell-wall degrading enzymes production in fungi}

The production of CWDEs by fungi is an energy-consuming process. The fine-tuned regulation of genes encoding CWDEs ensures that these enzymes will be produced only under conditions in which the fungus requires plant polymers as carbon source. Readily metabolizable carbohydrates repress the synthesis of enzymes related to catabolism of alternative carbon sources such as plant cell wall polysaccharides. In this way, preferential utilization of the most favored carbon source prevails, and one of the regulatory mechanisms involved in this adaptation is carbon catabolite repression (CCR). The CCR is activated by many carbon sources, depending on the lifestyle of the microorganism, but usually glucose is the most repressive molecule [75]. Nowadays, the search for microorganisms able to efficiently degrade lignocellulosic biomass is pivotal for the establishment of sustainable production of biomass-derived ethanol and other biocompounds. In this context, CCR appears as a major challenge to overcome, once this mechanism is responsible for enzymatic exclusion of less preferred carbon source such as lignocellulose-derived sugars. Hence, the comprehension of molecular mechanisms behind CCR, as well as the transcriptional control of cell wall derived enzymes are prerequisite in order to develop new microbial strains for lignocellulose degradation. In this section, the induction of expression of cellulases and hemicellulases, the transcriptional control of genes encoding CWDEs and the overall mechanism behind CCR will be discussed. 


\section{Induction of cellulases}

Although the biochemistry of the process behind lignocellulosic degradation has been studied in detail, the mechanism by which filamentous fungi sense the substrate and initiate the overall process of hydrolases production is still unsolved. Some researchers have been proposed that a low constitutive level of cellulase expression is responsible for the formation of an inducer from cellulose, amplifying the signal. Another group of scientists suggest that the fungus initiates a starvation process, which could in turn activates cellulase/hemicellulase expression. Also, it is possible that an inducing sugar derived from carbohydrates released somehow from the fungal cell wall could be the derepressing molecules for hydrolase induction. Despite of the fact that the true mechanism behind natural cellulase/hemicellulase induction is still lacking, some individual molecules are known to induce these hydrolases.

The fungus Trichoderma ressei is an impressive producer of cellulases and most of studies concerning the regulation of cellulase genes have been performed in this specie. The most powerful inducer of cellulases in T. reesei is sophorose, a disaccharide composed of $\beta-1,2-$ linked glucose units. Sophorose appears to be formed from cellobiose through transglycosylation activity of $\beta$-glucosidase [76 - 78]. In addition to T. reesei, sophorose is known to induce cellulase expression in A. terreus and P. purpurogenum [79 - 80].

Cellobiose (two $\beta$-1,4-linked glucose units) appears to induce cellulase expression in many species of fungi. Cellobiose is formed as the end product of cellobiohydrolases activity, and it has been show to induce cellulase expression in T. reesei, Volvariella volvacea, P. janthinellum and $A$. nidulans [81 - 84]. However, studies concerning the inducing effect of cellobiose on cellulase expression are controversial [6]. For instance, cellobiose can be transglycosylated by $\beta$-glucosidases, producing sophorose, which could be the true inducer of cellulases. Besides, $\beta$-glucosidases are able to cleave the cellobiose into glucose, which may cause repression by CCR. Therefore, the outcome in cellobiose cultures appears to be dependent on the balance between hydrolysis and transglycosylation, as well as the subsequent uptake of the generated sugars and the intracellular signals they initiate.

Lactose (1,4-O- $\beta$-D-galactopyranosyl-D-glucose) is a disaccharide that has been shown economically viable to induce cellulase expression in T. reesei. Interestingly, lactose is not a component of plant cell wall polymers and the mechanism through which this sugar induces cellulase expression appears to be complex. In filamentous fungi, lactose is cleaved by extracellular $\beta$-galactosidase into glucose and galactose. Lactose induction of cellulase genes requires the $\beta$-anomer of $\mathrm{D}$-galactose, which can be converted to fructose by an alternative pathway in addition to the Leloir pathway [85]. In this alternative pathway, D-xylose reductase (encoded by $x y l 1$ ) is the enzyme catalyzing the first step [86].

Moreover, induction of cellulase genes could be achieved in T. reesei cultures after addition of various other oligosaccharides such as laminaribiose, gentiobiose, xylobiose, L-sorbose and $\delta$-cellobiono-1,5-lactone. L-arabitol and different xylans also have been show to induce expression of cellobiohydrolase 1 (cbh1) in T. reesei (reviewed in reference [6]. 


\section{Induction of hemicellulases and pectinases}

Hemicellulase expression has been studied mostly in Aspergilli and T. reesei. However, a comparison of the genome sequences of T. reesei [87] and Aspergillus niger [88] demonstrated that $A$. niger is more versatile in the range of hemicellulases, and therefore this specie has become a very useful model fungus for basic studies on CWDEs in recent years. It is known that the presence of the hemicelluloses xylan, xyloglucan, arabinan and mannan usually induces a high production of hemicellulases, though the mechanism of sensing is still lacking, as assigned for cellulase induction. Usually, small hemicellulose-derived molecules are able to induce the expression of a wide range of hemicellulases.

The monosaccharide D-xylose is a well-known inducer of xylanolytic enzymes in Aspergillus species. In $A$. niger, D-xylose appears to induce other hydrolase genes rather than xylanase genes, such as the accessory enzymes $\alpha$-glucuronidase (aguA), acetylxylan esterase (axe $A)$ and feruloyl esterase $(f a e A)[89,90]$. Some results have been demonstrated that xylose can act as a repressor carbon source of hemicellulase induction at high concentrations [91], whereas other studies demonstrated that utilization of a high D-xylose concentration was beneficial for the induction of hemicellulase-encoding genes [92]. In addition to xylose, xylobiose and D-glucose- $\beta-1,2-\mathrm{D}$-xylose have been demonstrated to induce expression of xylanolytic genes in A. terreus [80].

The genes encoding enzymes responsible for the degradation of arabinoxylan in A. niger were induced by arabinose and L-arabitol. These genes encode enzymes such as arabinofuranosidases ( $a f b A$ and $a f b B$ ) and arabinoxylan arabinofuranosidases ( $a x h A)$ [6]. High intracellular accumulation of L-arabitol in A. nidulans mutant strains was able to induce higher amounts of arabinofuranosidases and endoarabinases than in the wild type strain [93]. The arabinolytic system appears to be independent from xylanolytic system in A. niger, as demonstrated by the isolation of ara mutants of $A$. niger defective for the induction of the genes encoding arabinolytic enzymes, but not for the induction of enzymes belonging to xylanolytic system [94].

Regarding to pectinolytic enzymes, D-galacturonic acid, polygalacturonate and sugar beet pectin have been shown to induce virtually all the genes encoding for pectin degradation enzymes in A. niger, suggesting that these genes are under the control of a general pectinolytic regulatory system responding to D-galacturonic acid or a metabolic product derived from it in A. niger [48, 90].

In T. ressei, the induction of hemicellulases was observed during growth in the presence of cellulose, xylan, sophorose, xylobiose and L-arabitol [6]. A xylanase gene (xyn2) was induced by sophorose and xylobiose $[95,96]$. Xylobiose was able to induce genes involved in xylan degradation in $T$. reesei, such as the xylanase genes $x y n 1$ and $x y n 2$ and the $\beta$-xilosidase gene $b x l 1$. In addition, sophorose induced some genes encoding enzymes that cleave the side chains of xylan such as agl1 and agl2 ( $\alpha$-galactosidase genes), and glr1, encoding a $\alpha$ glucuronidase gene [97].

Complex mixtures of polysaccharides have been shown to induce a wide range of cellulases/ hemicellulases genes in A. niger. For instance, sugarcane bagasse, a by-product of sugar/ 
ethanol factories, was able to induce a variety of cell-wall degrading enzyme genes in $A$. niger [98]. This is especially important for the development of second-generation ethanol (cellulosic ethanol) technology in countries producing ethanol from sugarcane, which could be able to use a very cheap raw material to produce the biofuel.

\section{Induction of ligninases}

The ligninolytic system of many fungi appears to be induced under nutrient deprivation, mainly nitrogen, carbon and sulphur. Therefore, the expression of most of the ligninolytic genes is regarded as a stress response to nutrient deprivation. Also, the presence of $\mathrm{Mn}(\mathrm{II})$ is required for induction of manganese peroxidase (MnPs) genes in the white-rot fungi P. chrysosporium [99 - 101]. Besides nutrient depletion and the presence of $\mathrm{Mn}(\mathrm{II}), \mathrm{MnP}$ genes were found to be expressed under heat shock in nitrogen limited cultures [102], and in the presence of $\mathrm{H}_{2} \mathrm{O}_{2}$, chemical stress or molecular oxygen [103]. Similarly, lignin peroxidase (LiP) genes are also expressed under carbon and nitrogen limitation in P. chrysosporium [104].

Laccases are multicopper oxidase proteins, and therefore can be induced by copper, although other metals can induce the expression of laccase genes as well, such as manganese and cadmium [105, 106]. Many natural and xenobiotic aromatic compounds, which are often related to lignin or humic substances, were shown to induce genes related to laccases [107]. In general, it has been postulated that laccases are the first enzymes degrading lignin, and possible further degradation products released from the polymer could act as inducers to amplify laccase expression, and subsequently induce other ligninolytic genes [105].

\section{Transcription factors involved in the expression of cellulase and hemicellulase-encoding genes}

A number of genes encoding plant cell wall degrading enzymes appears to present in their promoter regions regulatory elements for binding of transcriptional activators. The filamentous fungi $A$. niger and T. reesei have been the subject of many studies regarding the mechanism of transcriptional regulation of cellulase- and hemicellulase-encoding genes. Also, genes responsible for the expression of transcription factors found in A. niger and T. reesei have their homologs in other Aspergilli species and Neurospora crassa. In this section, the main transcription regulators involved in plant-polysaccharide degradation found in fungi are presented.

\section{The transcriptional activator $X \ln R$}

Complementation by transformation of an $A$. niger mutant lacking xylanolytic activity led to the isolation of $x \ln R$ gene, a gene encoding the first known transcriptional activator controlling the expression of genes for xylanolytic and cellulolytic enzymes in filamentous fungi [108]. Ini- 
tially, it was thought that $X \ln R$ was able to regulate the expression of the xylanolytic genes encoding two endoxylanases $(x \ln B$ and $x \ln C)$ and a $\beta$-xylosidase $(x \ln D)$, and the transcription of genes encoding some accessory enzymes involved in xylan degradation including $\alpha$-glucuronidase $\mathrm{A}(\operatorname{ag} u A)$, acetylxylan esterase $\mathrm{A}(\operatorname{axe} A)$, arabinoxylan arabinofuranohydrolase $\mathrm{A}(\mathrm{ax}$ $h A)$, and feruloyl esterase A $(f a e A)$. Furthermore, $X \operatorname{lnR}$ has been found to activate the transcription of two endoglucanase-encoding genes, eglA and eglB, indicating that transcriptional regulation by $X \operatorname{lnR}$ includes cellulase-encoding genes [109]. Currently, it is known that $\mathrm{X} \operatorname{lnR}$ actually controls the transcription of about 20-30 genes encoding hemicellulases and cellulases, and a gene encoding a D-xylose reductase ( $x y r A)$, involved in intracellular D-xylose metabolism [110]. These results demonstrate an interconnection of extracellular xylan degradation and intracellular D-xylose metabolism, coupled via transcriptional regulation of xyr $A$ gene by $\mathrm{X} \ln R$. In this way, the fungus is able to adapt intracellular D-xylose metabolism to extracellular xylan degradation, indicating a high level of metabolic regulation. Based on these findings, a model was proposed to explain the activation of XlnR regulon [111]. Basically, carbon limitation minimize carbon catabolite repression, and this de-repressed condition favours monomeric sugars or their derivatives acting as inducers of cellulolytic/hemicellulolytic system. The nature of the monomeric sugar drives the polysaccharide enzyme system to be induced [110]. Figure 5 shows a schematic model for the regulation through $\mathrm{X} \operatorname{lnR}$ of genes encoding CWDEs in $A$. niger. Besides $A$. niger, the gene encoding $X \ln R$ has also been isolated from A. oryzae, where the corresponding protein AoXlnR demonstrated to control the expression of the xylanase-encoding genes $x y n F 1$ and $x y n F 2$ [112].

The $X \ln R$ transcriptional activator belongs to the class of zinc binuclear cluster domain proteins (PF00172) [113]. The DNA-binding domain is found in the XlnR at the N-terminal of the protein and, in addition to this domain, a fungal specific transcription factor domain is also present (PF04082) [110]. Functional studies have been demonstrated that a putative coiled-coil domain is important for the $X \ln R$ function, as the disruption of the $\alpha$-helix structure (Leu650Pro mutation) lead to cytoplasmic localization and loss of function of XlnR, due to a loss of transcription of the structural genes of the regulon [114]. As demonstrated by the same study, a C-terminal portion of $X \ln R$ appeared to be involved in transcriptional regulation, as a deletion of some amino acids of the C-terminus increased the expression of $\mathrm{X} \ln \mathrm{R}$ target genes, even under D-glucose repression conditions [114]. Efforts have been done in order to evaluate the behavior of $X \ln R$ regulon to optimize the expression of target genes. For instance, a modeling study for the observation of XlnR regulon dynamics under D-xylose induction was performed. In this study, it was demonstrated that regulation of the A. niger XlnR network system was dictated mainly by transcription and translation degradation rate parameters, and by Dxylose consumption profile $[115,116]$. Structural and functional studies of $X \ln R$ are pivotal for the development of new strains with improved cellulase/hemicellulase production, given its importance for the transcription of hydrolase-encoding genes.

\section{The transcriptional regulators Xyr1, Ace1 and Ace2}

In Aspergillus, the xylanolytic and cellulolytic enzymatic system is strictly co-regulated via the inducer D-xylose, while enzymes involved in the same systems in T. reesei are not mainly acti- 
vated by this sugar. As described above, the most potent inducer for cellulolytic system in T. reesei is sophorose, whereas hemicellulases appear to be induced during T. reesei growth in the presence of cellulose, xylan, sophorose, xylobiose and L-arabitol [6]. Despite of the diversity of inducers, it was demonstrated that the transcriptional regulation of the major hydrolytic enzyme-encoding genes cbh1, cbh2 and egl1 (cellulases), xyn1, xyn2 (xylanases) is dependent on Xyr1, the XlnR homologue in T. reesei. Xyr 1 appears to be an essential activator for all levels of xylanase genes $x y n 1$ and $x y n 2$ transcription, receiving or mediating different signals from the inducer molecules [114]. In $x y n 1$ and $x y n 2$ promoters, the Xyr1-binding elements resemble the consensus sequences of T. reesei transcriptional regulator Ace1 [117]. Ace1 apparently acts as an antagonist of the Xyr1-driven $x y n 1$ gene transcription. Deletion of $x y r 1$ gene in T. reesei led to increased expression of cellulase and xylanase genes studied in cellulose- and sophorose-induced cultures, suggesting a negative effect of Ace1 on the induced expression of these genes [118]. In contrast, ace 1 activated the $c b h 1$ promoter in yeast, suggesting that Ace1 could be able to act as an inducer or a repressor, depending on the context, but the mechanisms involved in such regulation still remain to be investigated [6].
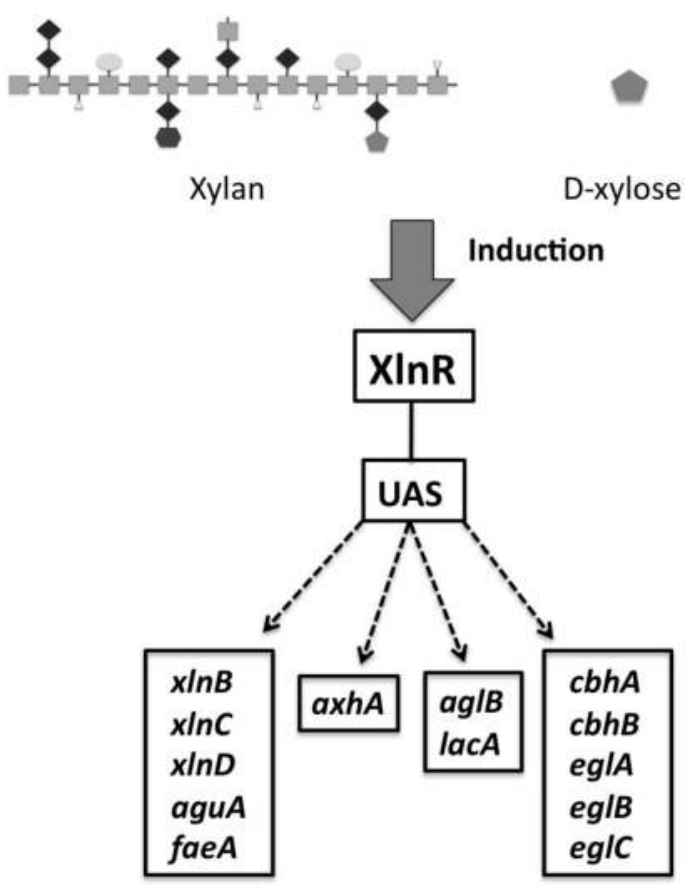

Figure 5. A proposed model for regulation of genes encoding polysaccharide-degrading enzymes in $A$. niger. Sugar monomers or polysaccharides provoke the binding of the transcription factor XInR to the upstream activating system (UAS) in the promoter region of the genes, inducing the respective enzymatic system. Genes encoding xylanases $(x \ln B, x \ln C)$, xylosidase $(x \ln D)$, glucuronidase $(a g u A)$ and feruloyl esterase $(f a e A)$ induce the xylanolytic enzymatic system. Genes encoding cellobiohydrolases $(c b h A, c b h B)$ and endoglucanases (eg/A, eg/B, eg/C) induce the cellulolytic system. Genes encoding galactosidases $(\mathrm{ag} / B, \mathrm{lac} A)$ induce the galactolytic system and the gene encoding arabinoxylan arabinofuranohydrolase induces the arabinolytic system. 
Ace2 belongs to a zinc-binuclear cluster DNA-binding protein and appears to be an activator of cellulase and hemicellulase genes in cellulose-induced cultures of T. reesei. Deletion of the ace 2 gene resulted in decreased expression of the cellulase genes cbh1, cbh2, egl1, egl2, and the xylanase gene $x y n 2$ upon $T$. reesei growth on cellulose as sole carbon source [119]. The same study has been demonstrated that the expression of these genes were not affected after $T$. reesei growing on sophorose, suggesting partially different mechanisms for hydrolase-encoding genes expression upon different carbon sources [119]. Homologs of ace2 in $A$. nidulans, A. niger, N. crassa and Magnaporthe grisea were not found to date, suggesting that different transcriptional regulators are used by these fungi to induce the expression of hydrolytic-encoding genes.

\section{Other regulators involved in plant polysaccharide degradation in Aspergilli}

The enzymatic system responsible for plant polysaccharide degradation is induced and commonly amplified after releasing of the plant cell wall polymers components. Two important components of the plant cell wall are D-xylose and L-arabinose, present in the polymers arabinan, arabinogalactan, xyloglucan and xylan. In Aspergilli, D-xylose and L-arabinose are catabolized through the pentose catabolic pathway, PCP [120], consisting of a series of reversible reductase/dehydrogenase steps culminating with the formation of D-xylulose-5phosphate, which enters the pentose phosphate pathway (PPP). In A. niger, the most of the genes involved in PCP have been characterized [110, 121 - 123]. In the presence of D-xylose, the transcriptional activator $\mathrm{X} \operatorname{lnR}$ is known to regulate the expression of genes not only encoding extracellular polysaccharide-degrading enzymes, but also regulates the expression of $x y r A$, the gene encoding D-xylose reductase, involved in the PCP [5]. L-arabinose induction of PCP is not mediated via XlnR, and the genes of the L-arabinose catabolic pathway are coregulated with genes encoding arabinolytic enzymes such as $\alpha$-L-arabinofuranosidase and endoarabinanase [93, 124]. A L-arabinose catabolic pathway regulator, AraR, was identified in $A$. niger, and appeared to act as antagonist of the XlnR in the regulation of PCP [125]. AraR demonstrated to regulate the L-arabinose pathway specific genes, for instance, the Larabitol dehydrogenase encoding gene (ladA) [125]. In addition, the L-arabinose reductase and L-xylulose reductase encoding genes (lar $A$ and $\operatorname{lx} r A$, respectively) appeared to be under the regulation of the arabinolytic system $[125,126]$. AraR and XlnR both regulate the common steps of L-arabinose and D-xylose catabolism, represented by xylitol dehydrogenaseand xylulose kinase-encoding genes, $x d h A$ and $x k i A$, respectively [123, 125]. Comparative analysis have been shown that the regulation of PCP by AraR differs in A. nidulans and $A$. niger, whereas the regulation of the PCP by $\mathrm{X} \operatorname{lnR}$ was similar in both species, suggesting different evolutionary changes in these two species affecting pentose utilization [125]. These authors suggest that the differences in Aspergilli species implies that manipulating regulatory systems to improve the production of polysaccharide degrading enzymes may give different results in different industrial fungi. 
Furthermore, it was found that in Aspergillus aculeatus, a new XlnR-independent pathway for the regulation of cellulase- and hemicellulase-encoding genes exists [127]. This study suggests that cellobiose from Avicel (crystalline cellulose) degradation stimulates only the XlnR-independent signaling pathway for cellulase/hemicellulase production in A. aculeatus. In addition, sequential promoter truncation studies on $c b h 1$ gene demonstrated that a conserved sequence in the promoter region of $c b h 1$, namely CeRe (required for eglA induction in A. nidulans; [128], plays a pivotal role on the expression regulated by the $X \operatorname{lnR}$-independent signaling pathway triggered by cellulosic compounds in A. aculeatus [127].

AmyR is another transcriptional activator found in Aspergilli. AmyR was first described as a transcriptional regulator of genes encoding enzymes involved in starch and maltose hydrolysis [129]. Nowadays, studies have been demonstrated a broader role for AmyR, which appears to regulate another gene expression systems. High levels of both $\alpha$ - and $\beta$-glucosidase as well as $\alpha$ - and $\beta$-galactosidase in the amyR multicopy strain of $A$. niger were found [130]. This study also demonstrated that AmyR-regulated genes in A. niger are induced during growth in low levels of D-glucose, as their expression increased during the cultivation. As D-glucose has been shown to act as a repressor through the carbon catabolite repressor protein CreA [75] (see next section), the authors suggested that repression levels of those genes are likely a balance between induction through AmyR and repression through CreA. Similar results were obtained for AmyR in Aspergillus oryzae [131].

\section{Transcriptional regulators of plant polysaccharide degradation genes in Neurospora crassa}

The filamentous ascomycete fungus Neurospora crassa has been commonly used as a model laboratory organism [132]. In nature, N. crassa can be found on burnt plant material, primarily grasses, including sugarcane and Miscanthus [133]. Previous studies have been demonstrated that $N$. crassa is able to express and secrete many plant cell wall degrading enzymes after grown on ground Miscanthus stems and crystalline cellulose [134]. Studies conducted with strains containing deletions of predicted transcription factors (TFs) in N. crassa demonstrated that a specific TF, named XLR1 (xylan degradation regulator-1), is essential for hemicellulose degradation in $N$. crassa [135]. The $x l r-1$ gene is an ortholog to $\mathrm{X} \operatorname{lnR} / \mathrm{Xyr} 1$ found in Aspergillus and Trichoderma species, respectively. The results presented in this study have been shown that deletion of $x l r-1$ in $N$. crassa abolished growth on xylan and xylose, but growth on cellulose and cellulolytic activities were not highly affected. The transcriptional profiling showed that $x l r-1$ is required for induction of hemicellulase and xylose metabolism genes, and modulated the expression levels of few cellulase genes, but these genes do not require XLR-1 for induction [135]. These findings suggested that unknown TFs in N. crassa could be important for the induced expression of genes encoding cellulases in response to the presence of cellulose.

In fact, studies assessing a near-full genome deletion strain set in N. crassa, have been shown two transcription factors, named $c l r-1$ and $c l r-2$, required for degradation of cellulose [136]. 
Homologs of $c l r-1$ and $c l r-2$ are present in the genomes of many filamentous ascomycete species capable of degrading plant-cell wall material, including A. nidulans. The $N$. crassa TFs $c l r-1$ and $c l r-2$ were able to induce all major cellulase and some hemicellulase genes, and functional CLR-1 was necessary for the expression of $c l r-2$ and efficient cellobiose utilization by the fungus. Besides, in $A$. nidulans, a deleted strain of the $c l r-2$ homolog $(c l r B)$ failed to induce cellulase gene expression and lacked cellulolytic activity on Avicel [136]. These authors reinforced the idea that further manipulation of the transcriptional regulation of cellulase/hemicellulase system may improve yields of cellulases for industrial applications, e.g., for biofuel production.

\section{Carbon catabolite repression in Aspergilli}

As briefly described above, microorganisms are known to adjust their carbon metabolism in order to minimize energy demands. One of these regulatory mechanisms is the carbon catabolite repression (CCR). Readily metabolizable carbon sources, such as glucose, are preferably catabolized and, in general, suppress the utilization of alternative carbon sources, repressing mainly the enzymatic system required for the catabolism of less favorable carbohydrates. For general carbon catabolite repression in some Aspergilli species, the DNA-binding $\mathrm{Cys}_{2} \mathrm{His}_{2}$ zinc-finger repressor CreA is absolutely necessary [75]. In general, the negative effect of this regulatory system depends on the concentration of the preferable carbon source (elicitor). For instance, higher concentrations of the elicitor usually induce stronger transcriptional repression [137]. The presence of the repressing elicitors initiates signal transduction pathways to result in transcriptional repression of the catabolism of poor carbon sources. In this context, the molecular mechanisms leading to CCR is well known for the ethanol utilization in A. nidulans, and therefore ethanol catabolism in this specie is commonly used as a model for studying CCR gene regulation [138]. In $A$. nidulans, ethanol, ethylamine and L-threonine can be used as sole carbon sources via their conversion into acetaldehyde and acetate [139, 140]. Furthermore, acetate enters the main metabolism in its activated form, acetyl-CoA. Alcohol dehydrogenase I (alcA gene) and aldehyde dehydrogenase (ald $A$ gene) are the two enzymes involved in the oxidation of ethanol into acetate. The genes alc $A$ and ald $A$ are activated through the transcriptional regulator AlcR in the presence of a co-inducer compound [141]. AlcR is a positive regulatory protein of the zinc binuclear class, is autoregulated and binds to specific sites on the alc $A$ and alcR promoter regions.

In this context, CreA appears as a sole transcriptional repressor of the system, exerting its function in the presence of a co-repressor [139, 142 - 143]. It is well known that in the alc genes repression system, CreA exerts its repressing function in three main different levels: (i) direct repression of alcR; (ii) indirect repression, via alcR repression, of the structural genes (aldA and alcM); and (iii) combined direct and indirect repression of the structural al$c A$ and alcS genes, by the "double-lock" mechanism. At the molecular level, a competition between AlcR and CreA results in partial repression of the alcR gene and a complete repression of alcA. This mechanism is important under growth conditions in which poor carbon 
sources such as ethanol are simultaneously present with high amounts of a preferable carbon source such as glucose, and the fungus is able to fine-tune the regulation in order to adapt to new nutrient. A second mechanism involves complete repression of the alcR gene, operating at high glucose concentration. Under these conditions, expression of the alc genes does not occur, and the fungus metabolizes only the rich carbon source (reviewed in [141]).

A variety of studies have been demonstrated the mechanisms through which CreA represses some polysaccharide-degrading enzymatic systems in fungi. It was shown that CreA appears to repress $x \ln A$ transcription by the "double-lock" mechanism in A. nidulans, repressing directly the gene through its binding to the consensus $x \ln A . \mathrm{C} 1$ site of the promoter, as well as indirect repression [144]. Studies on A. nidulans $x \ln B$ gene repression demonstrated that the four CreA target sites located in $x \ln B$ gene promoter region lack physiological relevance, suggesting that the repression exerted by CreA on $x \ln B$ is by an indirect mechanism [145]. The latter results suggested that an additional level of CreA repression via the xylanolytic activator is present in $A$. nidulans. The authors suggested that this mechanism of regulation would be analogous to that described above for the alc regulon, where certain genes are under a double-lock mechanism of repression by CreA while others are not subject to direct repression, being regulated via CreA repression of the alcR regulatory gene. In fact, studies have been shown that the $x \ln R$ (the xylanolytic transcriptional activator) promoter is repressed by glucose via CreA in $A$. nidulans, and when this repression is eliminated, by promoter exchange, transcription of xylanolytic genes such as $x \ln A, x \ln B$ and $x \ln D$ is derepressed [146]. These results demonstrated that a transcription factor cascade involving CreA and XlnR regulates CCR of $A$. nidulans xylanolytic genes.

F-box proteins are proteins containing at least one F-box domain in their structures. The Fbox domain is a protein structural motif of about 50 amino acids that mediates protein-protein interactions [147]. Usually, F-box proteins mediate ubiquitination of proteins targeted for degradation by the proteasome, but these proteins have also been associated with cellular functions such as signal transduction and regulation of cell-cycle [148]. A study that performed a screening of $42 \mathrm{~A}$. nidulans F-box deletion mutants grown either on xylose or xylan as a sole carbon source in the presence of 2-deoxy-D-glucose was able to identify mutants with de-regulated xylanase induction [149]. In this study, a null mutant in a gene $(f b x A)$ with decreased xylanase activity and reduced $x \ln A$ and $x \ln D$ mRNA accumulation was identified. This mutant interacted genetically with creA mutants, emphasizing the importance of the CCR and ubiquitination in the A. nidulans xylanase induction. In addition, the identification of FbxA protein provides evidence for another level of regulatory network concerning xylanase induction in filamentous fungi [149].

In summary, an intricate and fine-tuned regulation network exists in order to control the expression of plant cell-wall degradation genes in fungi. A variety of transcriptional regulators are able to respond to different nutritional requirements of the fungus, depending on its lifestyle. In general, readily metabolizable carbon sources such as glucose represses the transcription of genes responsible for the poor carbon source catabolism, via different mechanisms. The carbon catabolite repression in fungi is a common mechanism of regulation through which the organism adapts to nutritional availability in their environment. For 
instance, in $A$. nidulans, the xylanolytic transcriptional activator $X \ln R$ is repressed by glucose via $\mathrm{CreA}$, the transcriptional factor responsible for CCR in this specie. The comprehension of such sophisticated regulatory network is essential for genetic engineering of new strains able to produce a wide range of lignocellulolytic enzymes.

\section{Improving microbial strains for degradation of lignocellulosic biomass}

In order to degrade efficiently plant biomass, a microorganism should possess characteristics that make the process economically viable. For cellulosic ethanol production, for instance, an efficient microorganism should produce high yields of the desired product, must have a broad substrate range and high ethanol tolerance and it has to be tolerant to the inhibitors present in lignocellulosic hydrolysates. Therefore, engineering microbial strains for improvement of effectiveness in industrial applications is not a simple task. Concerning to bioethanol production, the most promising organism for genetic bioengineering is the yeast Saccharomices cerevisiae. This microorganism has a great capacity for cell-recycle fermentation, and it is tolerant against various stresses, such as high temperature, low $\mathrm{pH}$ and many inhibitors [150]. Moreover, S. cerevisiae is a well-characterized model organism, with a diverse array of research tools and resources, which facilitates metabolic engineering [151, 152].

However, the metabolism of $S$. cerevisiae is very complex and punctual genetic modifications in the yeast may lead to unpredicted modifications in the whole metabolism, with undesired effects for industrial applications, such as generation of toxic by-products. In general, metabolic engineering of $S$. cerevisiae is performed on a trial-and error basis, with various modifications being tested at the same time. In this way, the most promising approaches are implemented to increase target production [153]. Due to this challenge, a novel and rational strategy has recently emerged for a system-wide modification of metabolism. The novel approach, termed synthetic bioengineering, is essential for creating effective yeast cell factories [152 - 154]. The first step in the synthetic bioengineering consists of an optimized metabolic pathway designed by computational simulation. Based on this metabolic profile, a list of target genes to be inserted or deleted is determined. Next, a customized microbial cell factory is assembled using advanced gene manipulation techniques. After the detection of metabolic problems concerning the prototype strains by using transcriptomics and metabolomics, further improvement of the assembled strains are performed [153]. Currently, many researchers have been using synthetic bioengineering approaches to improve microbial strains for industrial applications. For instance, efforts have been done in order to produce S. cerevisiae strains able to use xylose as carbon source, once this sugar is the second most abundant in lignocellulosic biomass. The yeast is not able to ferment xylose, but some groups already produced S. cerevisiae strains with improved capacity of xylose fermentation [30, 155 - 156]. A detailed description of synthetic bioengineering and its applications could be found at [153]. In this review, the authors describe engineered microbial strains producing higher alcohols such as 1-butanol and isobutanol and strains overproducing glutathione, for instance. 
It is worth to mention that synthetic bioengineering could be applied for any microorganism, since it is a rational design of metabolic pathways.

While most biological routes being studied for the processing of lignocellulosic biomass focused on the separate production of hydrolytic enzymes, in a process that usually comprises several steps, another approach is suggested to achieve this goal. This approach, termed consolidated bioprocessing (CBP) involves the production of cellulolytic enzymes, hydrolysis of biomass, and fermentation of resulting sugars in a single stage via microorganisms or a consortium [157]. CBP appears to offer very large costs reduction if microorganisms can be developed that possess the required combination of substrate utilization and product formation properties [158]. In a 2006 report in biomass conversion to biofuels, the U.S. Department of Energy endorsed the view that CBP technology is "the ultimate low-cost configuration for cellulose hydrolysis and fermentation" (DOE Joint Task Force, 2006; energy.gov). Currently, CBP technology is developing fast, especially due to partnerships with venture capital investors and researchers. The main challenge of CBP is to generate engineered microorganisms able to produce the saccharolytic enzymes and converting the sugars released by those enzymes into the desired end-products. In addition, CBP microorganisms need to be able to perform these tasks rapidly and efficiently under challenging, industrial processes. A successful microbial platform for production of bioethanol from microalgae is currently available, and demonstrates an application of the CBP [159]. A DNA fragment encoding enzymes for alginate transport and metabolism from Vibrio splendidus, abundant and ubiquitous marine bacteria, was introduced in the genome of Escherichia coli, a well-characterized microorganism. This microbial platform was able to simultaneously degrade, uptake and metabolize alginate, an abundant polysaccharide present in microalgae. When further engineered for ethanol synthesis, this platform enabled bioethanol production with satisfactory yield directly from microalgae via a consolidated bioprocess [159].

The approach required for generation of CBP microorganisms involves the knowledge of many topics discussed in this chapter, concerning to fundamental principles of microbial cellulose utilization and its regulation. Moreover, the principles of synthetic bioengineering discussed above can be applied to the development of new strains for CBP technology, and therefore the generation of new microbial platforms able to uptake and metabolize completely the lignocellulosic biomass.

\section{Conclusions and future perspectives}

A large quantity of lignocellulosic residues is accumulating over the world, mainly due to the expansion of industrial processes, but other sources such as wood, grass, agricultural, forestry and urban solid wastes contribute to accumulation of lignocellulosic material. These residues constitute a renewable resource from which many useful biological and chemical products can be derived. The natural ability of fungi and other microorganisms to degrade lignocellulosic biomass, due to highly efficient enzymatic systems, is very attractive for the development of new strategies concerning industrial processes. Paper manufacture, com- 
posting, human and animal feeding, economically important chemical compounds and biomass fuel production are among some industrial applications derived from microbial lignocellulosic degradation.

Global climate change and future energy demands initiate a race in order to achieve sustainable fuels derived from biomass residues. Conversion of sugars to ethanol is already currently done at very low cost from sugarcane in Brazil, and from corn, in United States. However, the challenge is how to obtain the biofuel from the wastes generated from the mills producing ethanol. Residues such as sugarcane bagasse and corncobs contain large amounts of lignocellulosic material and therefore can be transformed into biofuels. A major advantage of using residues to produce biofuels is to reduce the competition between fuels and food. In this context, hydrolytic enzymes such as cellulases contribute for the large cost of cellulosic ethanol nowadays. The great bottleneck to achieve cellulosic biofuels is the plant biomass recalcitrance, and overcome such barrier is the key for the development of feasible industrial processes for biofuels production. For instance, it was recently demonstrated that Aspergillus niger growing on steam-exploded sugarcane bagasse was able to produce and secrete a high number of (hemi)cellulases [98]. The challenge is to adapt the process of steam explosion of a waste residue, such as sugarcane bagasse, with its hydrolysis by the fungi. The steam-explosion is a pretreatment that can decrease biomass recalcitrance, allowing the fungi to penetrate deeply within the biomass.

The comprehension of the machinery behind the enzymatic systems of fungi able to degrade plant cell wall polysaccharides favors the use of the microorganisms in industrial applications. Currently, through advanced molecular techniques, it is possible to engineer new microbial strains by insertion or deletion of genes involved in important metabolic pathways responsible for biomass degradation. The useful host cells to develop the synthetic bioengineering should have versatile genetic tools, resources and suitability for bio-refinery processes, such as stress tolerance. Therefore, a strain development in future requires insertion, deletion and expression controls of multiple genes and it is a difficult task to achieve. However, integrated advanced techniques could be able to overcome these challenges, including computational simulation of metabolic pathways, genome synthesis, directed evolution and minimum genome factory. The synthesis of the whole genome has already been done [160,162] and, as discussed in reference [153], in a near future the synthesis of very large fragments of DNA will make it possible to design a whole yeast artificial chromosome (YAC) encoding a number of genes. According to these authors, the de novo synthesis of YAC should be a breakthrough methodology for the future synthetic bioengineering, and cloning of individual genes and a construction of plasmid vectors would be obsolete. A rational design of metabolic pathways along with customized design of genes with optimized expression may be obtained, making it possible to produce a whole sequence of the artificial chromosome $[153,163]$.

As said by Lee Lynd, a pioneering researcher in the field of biomass: "the first step toward realizing currently improbable futures is to show that they are possible". These technologies described above are currently available for scientific community and, along with advances in industrial processes, endorse the possibility to take energy from plant biomass using microorganisms. Thus, the Humanity has never been so close to use new and sustainable ways of energy. 


\section{Author details}

Wagner Rodrigo de Souza*

Address all correspondence to: wagnerusp@gmail.com

Institute of Biology, State University of Campinas (UNICAMP), Brasil

\section{References}

[1] Goldemberg J, Coelho ST. Renewable energy - traditional biomass vs. modern biomass. Energ Policy. 2004 Mar;32(6):711-4. PubMed PMID: ISI:000187896900001. English.

[2] Himmel ME. Biomass recalcitrance: engineering plants and enzymes for biofuels production (vol 315, pg 804, 2007). Science. 2007 May 18;316(5827):982-. PubMed PMID: ISI:000246554000023. English.

[3] de Vries R, Visser, J. . Aspergillus enzymes involved in degradation of plant cell wall polysaccharides. . Microbiology and Molecular Biology Reviews. 2001;65(4):497-522.

[4] Aro N, Pakula, T, Penttila, M. . Transcriptional regulation of plat cell wall degradation by filamentous fungi. FEMS Microbiology Reviews. 2005;29:719-39.

[5] de Vries RP. Regulation of Aspergillus genes encoding plant cell wall polysaccharide-degrading enzymes; relevance for industrial production. Appl Microbiol Biotechnol. 2003 Mar;61(1):10-20. PubMed PMID: 12658510. Epub 2003/03/27. eng.

[6] Aro N, Pakula T, Penttila M. Transcriptional regulation of plant cell wall degradation by filamentous fungi. FEMS microbiology reviews. 2005 Sep;29(4):719-39. PubMed PMID: 16102600.

[7] Lynd LR WP, van Zyl WH, Pretorius IS. Microbial cellulose utilization: Fundamentals and biotechnology. Microbiology and Molecular Biology Reviews. 2002;66(3): 506-77.

[8] Lynd LR, Weimer PJ, van Zyl WH, Pretorius IS. Microbial cellulose utilization: Fundamentals and biotechnology (vol 66, pg 506, 2002). Microbiology and Molecular Biology Reviews. 2002 Dec;66(4):739-. PubMed PMID: ISI:000179683700007. English.

[9] Lee S, Ha, JK, Kang, HS, McAllister T, Cheng K-J. . Overview of energy metabolism, substrate utilization and fermentation characteristics of ruminal anaerobic fungi. Korean Journal of Animal and Nutritional Feedstuffs. 1997;21:295-314.

[10] Lobarzewski J. The Characteristics and Functions of the Peroxidases from TrametesVersicolor in Lignin Biotransformation. J Biotechnol. 1990 Feb;13(2-3):111-7. PubMed PMID: ISI:A1990CU51000003. English. 
[11] Galliano H, G. Gas, J.L. Sevis and A.M. Boudet: Lignin degradation by Rigidoporus lignosus involves synergistic action of two oxidizing enzymes: Mn peroxidase and laccase. . Enzyme Microb Technol. 1991;13:478-82.

[12] Stricker SH, Steenpass L, Pauler FM, Santoro F, Latos PA, Huang R, et al. Silencing and transcriptional properties of the imprinted Airn ncRNA are independent of the endogenous promoter. Embo Journal. 2008 Dec 3;27(23):3116-28. PubMed PMID: ISI: 000261330900004. English.

[13] Stricker AR, Mach RL, de Graaff LH. Regulation of transcription of cellulases- and hemicellulases-encoding genes in Aspergillus niger and Hypocrea jecorina (Trichoderma reesei). Appl Microbiol Biot. 2008 Feb;78(2):211-20. PubMed PMID: ISI: 000252614200003. English.

[14] Bayer EA, Belaich JP, Shoham Y, Lamed R. The cellulosomes: multienzyme machines for degradation of plant cell wall polysaccharides. Annu Rev Microbiol. 2004;58:521-54. PubMed PMID: 15487947.

[15] Fontes CM, Gilbert HJ. Cellulosomes: highly efficient nanomachines designed to deconstruct plant cell wall complex carbohydrates. Annual review of biochemistry. 2010;79:655-81. PubMed PMID: 20373916.

[16] Kosugi A, Murashima K, Doi RH. Xylanase and acetyl xylan esterase activities of XynA, a key subunit of the Clostridium cellulovorans cellulosome for xylan degradation. Appl Environ Microbiol. 2002 Dec;68(12):6399-402. PubMed PMID: 12450866. Pubmed Central PMCID: 134393.

[17] Morag E, Bayer EA, Lamed R. Relationship of cellulosomal and noncellulosomal xylanases of Clostridium thermocellum to cellulose-degrading enzymes. J Bacteriol. 1990 Oct;172(10):6098-105. PubMed PMID: 2211528. Pubmed Central PMCID: 526935.

[18] Tamaru Y, Doi RH. Pectate lyase A, an enzymatic subunit of the Clostridium cellulovorans cellulosome. Proc Natl Acad Sci U S A. 2001 Mar 27;98(7):4125-9. PubMed PMID: 11259664. Pubmed Central PMCID: 31190.

[19] Salamitou S, Raynaud O, Lemaire M, Coughlan M, Beguin P, Aubert JP. Recognition specificity of the duplicated segments present in Clostridium thermocellum endoglucanase CelD and in the cellulosome-integrating protein CipA. J Bacteriol. 1994 May; 176(10):2822-7. PubMed PMID: 8188583. Pubmed Central PMCID: 205435.

[20] Tokatlidis K, Salamitou S, Beguin P, Dhurjati P, Aubert JP. Interaction of the duplicated segment carried by Clostridium thermocellum cellulases with cellulosome components. FEBS Lett. 1991 Oct 21;291(2):185-8. PubMed PMID: 1936262.

[21] Poole DM, Morag E, Lamed R, Bayer EA, Hazlewood GP, Gilbert HJ. Identification of the cellulose-binding domain of the cellulosome subunit S1 from Clostridium thermocellum YS. FEMS Microbiol Lett. 1992 Dec 1;78(2-3):181-6. PubMed PMID: 1490597. 
[22] Mingardon F, Chanal A, Lopez-Contreras AM, Dray C, Bayer EA, Fierobe HP. Incorporation of fungal cellulases in bacterial minicellulosomes yields viable, synergistically acting cellulolytic complexes. Appl Environ Microbiol. 2007 Jun;73(12):3822-32. PubMed PMID: 17468286. Pubmed Central PMCID: 1932714.

[23] Mingardon F, Perret S, Belaich A, Tardif C, Belaich JP, Fierobe HP. Heterologous production, assembly, and secretion of a minicellulosome by Clostridium acetobutylicum ATCC 824. Appl Environ Microbiol. 2005 Mar;71(3):1215-22. PubMed PMID: 15746321. Pubmed Central PMCID: 1065181.

[24] McClendon SD, Mao Z, Shin HD, Wagschal K, Chen RR. Designer xylanosomes: protein nanostructures for enhanced xylan hydrolysis. Appl Biochem Biotechnol. 2012 Jun;167(3):395-411. PubMed PMID: 22555497.

[25] Lee J. Biological conversion of lignocellulosic biomass to ethanol. J Biotechnol. 1997 Jul 23;56(1):1-24. PubMed PMID: 9246788.

[26] Galazka JM, Tian CG, Beeson WT, Martinez B, Glass NL, Cate JHD. Cellodextrin Transport in Yeast for Improved Biofuel Production. Science. 2010 Oct 1;330(6000): 84-6. PubMed PMID: ISI:000282334500039. English.

[27] Hahn-Hagerdal B, Karhumaa K, Fonseca C, Spencer-Martins I, Gorwa-Grauslund MF. Towards industrial pentose-fermenting yeast strains. Appl Microbiol Biotechnol. 2007 Apr;74(5):937-53. PubMed PMID: 17294186. Epub 2007/02/13. eng.

[28] Chu BC, Lee H. Genetic improvement of Saccharomyces cerevisiae for xylose fermentation. Biotechnol Adv. 2007 Sep-Oct;25(5):425-41. PubMed PMID: 17524590.

[29] Jeffries TW. Engineering yeasts for xylose metabolism. Curr Opin Biotechnol. 2006 Jun;17(3):320-6. PubMed PMID: 16713243.

[30] Hahn-Hagerdal B, Karhumaa K, Jeppsson M, Gorwa-Grauslund MF. Metabolic engineering for pentose utilization in Saccharomyces cerevisiae. Adv Biochem Eng Biotechnol. 2007;108:147-77. PubMed PMID: 17846723. Epub 2007/09/12. eng.

[31] Tamakawa H, Ikushima S, Yoshida S. Ethanol production from xylose by a recombinant Candida utilis strain expressing protein-engineered xylose reductase and xylitol dehydrogenase. Biosci Biotechnol Biochem. 2011;75(10):1994-2000. PubMed PMID: 21979076.

[32] Cantarel B, Rancurel, C, Bernard, T, Lombard, V, Coutinho, PM, Henrissat, B. The Carbohydrate-Active EnZymes database: an expert resource for Glycogenomics. Nucleic Acids Research. 2009;37:D233-D8.

[33] van den Brink J, de Vries RP. Fungal enzyme sets for plant polysaccharide degradation. Appl Microbiol Biot. 2011 Sep;91(6):1477-92. PubMed PMID: ISI: 000294214900002. English.

[34] Dias FM, Vincent F, Pell G, Prates JA, Centeno MS, Tailford LE, et al. Insights into the molecular determinants of substrate specificity in glycoside hydrolase family 5 re- 
vealed by the crystal structure and kinetics of Cellvibrio mixtus mannosidase 5A. J Biol Chem. 2004 Jun 11;279(24):25517-26. PubMed PMID: 15014076. Epub 2004/03/12. eng.

[35] Beguin P. Molecular-Biology of Cellulose Degradation. Annu Rev Microbiol. 1990;44:219-48. PubMed PMID: ISI:A1990EA66200010. English.

[36] Ward M, Wu, S., Dauberman, J., Weiss, G., Larenas, E., Bower, B., Rey, M., Clarkson, $\mathrm{K}$. and Bott, R. Cloning, sequnece and preliminary structural analysis of a small, high pI endoglucanase (EGIII) form Trichoderma reesei (Suominen, P. and Reinikainen, T., Eds.), Trichoderma reesei cellulases and other hydrolases (TRICEL 93). Kirk-konummi, Finland.; 1993.

[37] Reczey K, Brumbauer A, Bollok M, Szengyel Z, Zacchi G. Use of hemicellulose hydrolysate for beta-glucosidase fermentation. Appl Biochem Biotechnol. 1998 Spring; 70-72:225-35. PubMed PMID: 18575992. Epub 2008/06/26. eng.

[38] Kubicek CP, Herrera-Estrella A, Seidl-Seiboth V, Martinez DA, Druzhinina IS, Thon $\mathrm{M}$, et al. Comparative genome sequence analysis underscores mycoparasitism as the ancestral life style of Trichoderma. Genome Biol. 2011;12(4):R40. PubMed PMID: 21501500. Pubmed Central PMCID: 3218866. Epub 2011/04/20. eng.

[39] Chen H, Hayn M, Esterbauer H. Purification and characterization of two extracellular beta-glucosidases from Trichoderma reesei. Biochim Biophys Acta. 1992 May 22;1121(1-2):54-60. PubMed PMID: 1599951. Epub 1992/05/22. eng.

[40] Polizeli ML, Rizzatti AC, Monti R, Terenzi HF, Jorge JA, Amorim DS. Xylanases from fungi: properties and industrial applications. Appl Microbiol Biotechnol. 2005 Jun; 67(5):577-91. PubMed PMID: 15944805. Epub 2005/06/10. eng.

[41] Biely P, Vrsanska M, Tenkanen M, Kluepfel D. Endo-beta-1,4-xylanase families: differences in catalytic properties. J Biotechnol. 1997 Sep 16;57(1-3):151-66. PubMed PMID: 9335171. Epub 1997/10/23. eng.

[42] Pollet A, Delcour JA, Courtin CM. Structural determinants of the substrate specificities of xylanases from different glycoside hydrolase families. Crit Rev Biotechnol. 2010 Sep;30(3):176-91. PubMed PMID: 20225927. Epub 2010/03/17. eng.

[43] Shinoyama H, A. Ando, T. Fujii, and T. Yasui. The possibility of enzymatic synthesis of a variety of -xylosides using the transfer reaction of Aspergillus niger xylosidase. Agric Biol Chem. 1991;55:849-50.

[44] Sulistyo J, Kamiyama Y, Yasui T. Purification and Some Properties of AspergillusPulverulentus Beta-Xylosidase with Transxylosylation Capacity. J Ferment Bioeng. 1995;79(1):17-22. PubMed PMID: ISI:A1995QF31200004. English.

[45] Pauly M, Andersen LN, Kauppinen S, Kofod LV, York WS, Albersheim P, et al. A xyloglucan-specific endo-beta-1,4-glucanase from Aspergillus aculeatus: expression cloning in yeast, purification and characterization of the recombinant enzyme. Glycobiology. 1999 Jan;9(1):93-100. PubMed PMID: 9884411. Epub 1999/01/13. eng. 
[46] Master ER, Zheng Y, Storms R, Tsang A, Powlowski J. A xyloglucan-specific family 12 glycosyl hydrolase from Aspergillus niger: recombinant expression, purification and characterization. Biochem J. 2008 Apr 1;411(1):161-70. PubMed PMID: 18072936. Epub 2007/12/13. eng.

[47] Desmet T, Cantaert T, Gualfetti P, Nerinckx W, Gross L, Mitchinson C, et al. An investigation of the substrate specificity of the xyloglucanase Cel74A from Hypocrea jecorina. FEBS J. 2007 Jan;274(2):356-63. PubMed PMID: 17229143. Epub 2007/01/19. eng.

[48] de Vries R V, J. Aspergillus enzymes involved in degradation of plant cell wall polysaccharides. Microbiology and Molecular Biology Reviews. 2001;65(4):497-522.

[49] Mccleary BV. Comparison of Endolytic Hydrolases That Depolymerize 1,4-Beta-DMannan, 1,5-Alpha-L-Arabinan, and 1,4-Beta-D-Galactan. Acs Sym Ser. 1991;460:437-49. PubMed PMID: ISI:A1991BT27V00034. English.

[50] Civas A, Eberhard R, Ledizet P, Petek F. Glycosidases Induced in Aspergillus-Tamarii - Secreted Alpha-D-Galactosidase and Beta-D-Mannanase. Biochem J. 1984;219(3): 857-63. PubMed PMID: ISI:A1984SQ61800022. English.

[51] Mccleary BV, Matheson NK. Action Patterns and Substrate-Binding Requirements of Beta-Deuterium-Mannanase with Mannosaccharides and Mannan-Type Polysaccharides. Carbohyd Res. 1983;119(Aug):191-219. PubMed PMID: ISI:A1983RE59300017. English.

[52] Ademark P, Lundqvist J, Hagglund P, Tenkanen M, Torto N, Tjerneld F, et al. Hydrolytic properties of a beta-mannosidase purified from Aspergillus niger. Journal of Biotechnology. 1999 Oct 8;75(2-3):281-9. PubMed PMID: ISI:000083683900019. English.

[53] Verbruggen MA, Spronk BA, Schols HA, Beldman G, Voragen AGJ, Thomas JR, et al. Structures of enzymically derived oligosaccharides from sorghum glucuronoarabinoxylan. Carbohyd Res. 1998 Jan;306(1-2):265-74. PubMed PMID: ISI: 000074837200026. English.

[54] Sakamoto T, Ogura A, Inui M, Tokuda S, Hosokawa S, Ihara H, et al. Identification of a GH62 alpha-l-arabinofuranosidase specific for arabinoxylan produced by Penicillium chrysogenum. Appl Microbiol Biot. 2011 Apr;90(1):137-46. PubMed PMID: ISI: 000288252000013. English.

[55] Yoshikawa K, Yamamoto K, Okada S. Isolation of Aspergillus flavus MO-5 producing two types of intracellular alpha-D-xylosidases: purification and characterization of alpha-D-xylosidase I. Biosci Biotechnol Biochem. 1993 Aug;57(8):1275-80. PubMed PMID: 7764013. Epub 1993/08/01. eng.

[56] Yoshikawa K, Yamamoto K, Okada S. Classification of some alpha-glucosidases and alpha-xylosidases on the basis of substrate specificity. Biosci Biotechnol Biochem. 1994 Aug;58(8):1392-8. PubMed PMID: 7765271. Epub 1994/08/01. eng. 
[57] Suykerbuyk ME, Schaap PJ, Stam H, Musters W, Visser J. Cloning, sequence and expression of the gene coding for rhamnogalacturonase of Aspergillus aculeatus; a novel pectinolytic enzyme. Appl Microbiol Biotechnol. 1995 Oct;43(5):861-70. PubMed PMID: 7576553. Epub 1995/10/01. eng.

[58] van der Vlugt-Bergmans CJ, Meeuwsen PJ, Voragen AG, van Ooyen AJ. Endo-xylogalacturonan hydrolase, a novel pectinolytic enzyme. Appl Environ Microbiol. 2000 Jan;66(1):36-41. PubMed PMID: 10618200. Pubmed Central PMCID: 91782. Epub 2000/01/05. eng.

[59] Lombard V, Bernard T, Rancurel C, Brumer H, Coutinho PM, Henrissat B. A hierarchical classification of polysaccharide lyases for glycogenomics. Biochem J. 2010 Dec 15;432(3):437-44. PubMed PMID: 20925655. Epub 2010/10/12. eng.

[60] Jurnak F, Kita N, Garrett M, Heffron SE, Scavetta R, Boyd C, et al. Functional implications of the three-dimensional structures of pectate lyases. Progr Biotechnol. 1996;14:295-308. PubMed PMID: ISI:A1996BJ39G00022. English.

[61] Isroi, Millati R, Syamsiah S, Niklasson C, Cahyanto MN, Lundquist K, et al. Biological Pretreatment of Lignocelluloses with White-Rot Fungi and Its Applications: A Review. Bioresources. 2011;6(4):5224-59. PubMed PMID: ISI:000298119500121. English.

[62] Hattaka A. Biodegradation of lignin. (eds.) MHaASc, editor: Wiley-WCH; 2001.

[63] Hammel KE, Cullen D. Role of fungal peroxidases in biological ligninolysis. Curr Opin Plant Biol. 2008 Jun;11(3):349-55. PubMed PMID: 18359268. Epub 2008/03/25. eng.

[64] Wong DW. Structure and action mechanism of ligninolytic enzymes. Appl Biochem Biotechnol. 2009 May;157(2):174-209. PubMed PMID: 18581264. Epub 2008/06/27. eng.

[65] Lundquist K, Kirk, T. K., and Connors, W. J. Fungal degradation of kraft lignin and lignin sulfonates prepared from synthetic 14C-lignins. Arch Microbiol. 1977;112:2916.

[66] Hatakka AI. Pretreatment of wheat straw by white-rot fungi for enzymatic saccharification of cellulose. Eur J Appl Microbiol Biotechnol. 1983;18:350-7..

[67] Kirk TK, and Chang, H.-M. Potential applications of bio-ligninolytic systems. Enzyme and Microbial Technology. 1981;3:189-96..

[68] Keller FA, Hamilton JE, Nguyen QA. Microbial pretreatment of biomass: potential for reducing severity of thermochemical biomass pretreatment. Appl Biochem Biotechnol. 2003 Spring;105 -108:27-41. PubMed PMID: 12721473. Epub 2003/05/02. eng.

[69] Lomascolo A, Uzan-Boukhris E, Herpoel-Gimbert I, Sigoillot JC, Lesage-Meessen L. Peculiarities of Pycnoporus species for applications in biotechnology. Appl Microbiol Biotechnol. 2011 Dec;92(6):1129-49. PubMed PMID: 22038244. 
[70] Eggert C, Temp U, Eriksson KE. The ligninolytic system of the white rot fungus Pycnoporus cinnabarinus: purification and characterization of the laccase. Appl Environ Microbiol. 1996 Apr;62(4):1151-8. PubMed PMID: 8919775. Pubmed Central PMCID: 167880 .

[71] Record E, Punt PJ, Chamkha M, Labat M, van Den Hondel CA, Asther M. Expression of the Pycnoporus cinnabarinus laccase gene in Aspergillus niger and characterization of the recombinant enzyme. Eur J Biochem. 2002 Jan;269(2):602-9. PubMed PMID: 11856319.

[72] Camarero S, Pardo I, Canas AI, Molina P, Record E, Martinez AT, et al. Engineering platforms for directed evolution of Laccase from Pycnoporus cinnabarinus. Appl Environ Microbiol. 2012 Mar;78(5):1370-84. PubMed PMID: 22210206. Pubmed Central PMCID: 3294479.

[73] Abbott TP, Wicklow DT. Degradation of lignin by cyathus species. Appl Environ Microbiol. 1984 Mar;47(3):585-7. PubMed PMID: 16346497. Pubmed Central PMCID: 239724.

[74] Salony, Mishra S, Bisaria VS. Production and characterization of laccase from Cyathus bulleri and its use in decolourization of recalcitrant textile dyes. Appl Microbiol Biotechnol. 2006 Aug;71(5):646-53. PubMed PMID: 16261367.

[75] Ruijter GJG, J. Visser. Carbon repression in aspergilli. FEMS Microbiology Letters. 1997;151:103-14.

[76] Gritzali MaB, R.D.J. The cellulase system of Trichoderma: relationship betweeen purified extracellular enzymes from induced or cellulose-grown cells. Adv Chem Ser. 1979;181:237-60.

[77] Vaheri M, Leisola, M. and Kauppinen, V. Transgly- cosylation products of cellulase system of Trichoderma reesei. Biotechnol Tech. 1979;1:696-9.

[78] Fowler T, Brown RD, Jr. The bgl1 gene encoding extracellular beta-glucosidase from Trichoderma reesei is required for rapid induction of the cellulase complex. Mol Microbiol. 1992 Nov;6(21):3225-35. PubMed PMID: 1453960. Epub 1992/11/11. eng.

[79] Bisaria VS, Mishra S. Regulatory aspects of cellulase biosynthesis and secretion. Crit Rev Biotechnol. 1989;9(2):61-103. PubMed PMID: 2509081. Epub 1989/01/01. eng.

[80] Hrmova M, Petrakova E, Biely P. Induction of cellulose- and xylan-degrading enzyme systems in Aspergillus terreus by homo- and heterodisaccharides composed of glucose and xylose. J Gen Microbiol. 1991 Mar;137(3):541-7. PubMed PMID: 2033377. Epub 1991/03/01. eng.

[81] Ilmen M, Saloheimo A, Onnela ML, Penttila ME. Regulation of cellulase gene expression in the filamentous fungus Trichoderma reesei. Appl Environ Microbiol. 1997 Apr;63(4):1298-306. PubMed PMID: 9097427. Pubmed Central PMCID: 168424. Epub 1997/04/01. eng. 
[82] Ding SJ, Ge W, Buswell JA. Endoglucanase I from the edible straw mushroom, Volvariella volvacea. Purification, characterization, cloning and expression. Eur J Biochem. 2001 Nov;268(22):5687-95. PubMed PMID: 11722552. Epub 2001/11/28. eng.

[83] Mernitz G, Koch A, Henrissat B, Schulz G. Endoglucanase II (EGII) of Penicillium janthinellum: cDNA sequence, heterologous expression and promotor analysis. Curr Genet. 1996 Apr;29(5):490-5. PubMed PMID: 8625430. Epub 1996/04/01. eng.

[84] Chikamatsu G, Shirai K, Kato M, Kobayashi T, Tsukagoshi N. Structure and expression properties of the endo-beta-1,4-glucanase A gene from the filamentous fungus Aspergillus nidulans. FEMS Microbiol Lett. 1999 Jun 15;175(2):239-45. PubMed PMID: 10386374. Epub 1999/07/01. eng.

[85] Fekete E, Padra J, Szentirmai A, Karaffa L. Lactose and D-galactose catabolism in the filamentous fungus Aspergillus nidulans. Acta Microbiol Imm H. 2008 Jun;55(2): 119-24. PubMed PMID: ISI:000256797900004. English.

[86] Seiboth B, Gamauf C, Pail M, Hartl L, Kubicek CP. The D-xylose reductase of Hypocrea jecorina is the major aldose reductase in pentose and D-galactose catabolism and necessary for beta-galactosidase and cellulase induction by lactose. Mol Microbiol. 2007 Nov;66(4):890-900. PubMed PMID: 17924946. Epub 2007/10/11. eng.

[87] Martinez D, Berka RM, Henrissat B, Saloheimo M, Arvas M, Baker SE, et al. Genome sequencing and analysis of the biomass-degrading fungus Trichoderma reesei (syn. Hypocrea jecorina). Nat Biotechnol. 2008 May;26(5):553-60. PubMed PMID: 18454138. Epub 2008/05/06. eng.

[88] Pel HJ, de Winde JH, Archer DB, Dyer PS, Hofmann G, Schaap PJ, et al. Genome sequencing and analysis of the versatile cell factory Aspergillus niger CBS 513.88. Nat Biotechnol. 2007 Feb;25(2):221-31. PubMed PMID: 17259976. Epub 2007/01/30. eng.

[89] de Vries RP, Visser J. Regulation of the feruloyl esterase (faeA) gene from Aspergillus niger. Appl Environ Microbiol. 1999 Dec;65(12):5500-3. PubMed PMID: 10584009. Pubmed Central PMCID: 91749. Epub 1999/12/03. eng.

[90] de Vries RP, van de Vondervoort PJ, Hendriks L, van de Belt M, Visser J. Regulation of the alpha-glucuronidase-encoding gene ( aguA) from Aspergillus niger. Mol Genet Genomics. 2002 Sep;268(1):96-102. PubMed PMID: 12242504. Epub 2002/09/21. eng.

[91] de Vries RP, Visser J, de Graaff LH. CreA modulates the XlnR-induced expression on xylose of Aspergillus niger genes involved in xylan degradation. Res Microbiol. 1999 May;150(4):281-5. PubMed PMID: 10376490. Epub 1999/06/22. eng.

[92] Mach-Aigner AR, Omony J, Jovanovic B, van Boxtel AJ, de Graaff LH. d-Xylose concentration-dependent hydrolase expression profiles and the function of CreA and XlnR in Aspergillus niger. Appl Environ Microbiol. 2012 May;78(9):3145-55. PubMed PMID: 22344641. Pubmed Central PMCID: 3346484. Epub 2012/02/22. eng. 
[93] de Vries RP, Flipphi MJ, Witteveen CF, Visser J. Characterization of an Aspergillus nidulans L-arabitol dehydrogenase mutant. FEMS Microbiol Lett. 1994 Oct 15;123(1-2):83-90. PubMed PMID: 7988903. Epub 1994/10/15. eng.

[94] de Groot MJ, van de Vondervoort PJ, de Vries RP, vanKuyk PA, Ruijter GJ, Visser J. Isolation and characterization of two specific regulatory Aspergillus niger mutants shows antagonistic regulation of arabinan and xylan metabolism. Microbiology. 2003 May;149(Pt 5):1183-91. PubMed PMID: 12724380. Epub 2003/05/02. eng.

[95] Mach RL, Strauss J, Zeilinger S, Schindler M, Kubicek CP. Carbon catabolite repression of xylanase I (xyn1) gene expression in Trichoderma reesei. Mol Microbiol. 1996 Sep;21(6):1273-81. PubMed PMID: 8898395. Epub 1996/09/01. eng.

[96] Zeilinger S, Mach RL, Schindler M, Herzog P, Kubicek CP. Different inducibility of expression of the two xylanase genes xyn1 and xyn2 in Trichoderma reesei. J Biol Chem. 1996 Oct 11;271(41):25624-9. PubMed PMID: 8810338. Epub 1996/10/11. eng.

[97] Margolles-Clark M, Ilme' n, M. and Penttila, M. Expression patterns of 10 hemicellulase genes from filamentous fungus Trichoderma reesei on various carbon sources. J Biotechnol. 1997;57:167-79..

[98] de Souza WR, de Gouvea PF, Savoldi M, Malavazi I, Bernardes LAD, Goldman MHS, et al. Transcriptome analysis of Aspergillus niger grown on sugarcane bagasse. Biotechnol Biofuels. 2011 Oct 18;4. PubMed PMID: ISI:000297110100001. English.

[99] Gold MH, Alic M. Molecular-Biology of the Lignin-Degrading Basidiomycete Phanerochaete-Chrysosporium. Microbiol Rev. 1993 Sep;57(3):605-22. PubMed PMID: ISI:A1993LW44100005. English.

[100] Gettemy JM, Ma B, Alic M, Gold MH. Reverse transcription-PCR analysis of the regulation of the manganese peroxidase gene family. Appl Environ Microbiol. 1998 Feb; 64(2):569-74. PubMed PMID: 9464395. Pubmed Central PMCID: 106084. Epub 1998/02/17. eng.

[101] Brown JA, Alic M, Gold MH. Manganese peroxidase gene transcription in Phanerochaete chrysosporium: activation by manganese. J Bacteriol. 1991 Jul;173(13):4101-6. PubMed PMID: 2061289. Pubmed Central PMCID: 208059. Epub 1991/07/01. eng.

[102] Mayfield MB, Godfrey BJ, Gold MH. Characterization of the mnp2 gene encoding manganese peroxidase isozyme 2 from the basidiomycete Phanerochaete chrysosporium. Gene. 1994 May 16;142(2):231-5. PubMed PMID: 8194756. Epub 1994/05/16. eng.

[103] Li D, Alic M, Brown JA, Gold MH. Regulation of manganese peroxidase gene transcription by hydrogen peroxide, chemical stress, and molecular oxygen. Appl Environ Microbiol. 1995 Jan;61(1):341-5. PubMed PMID: 7887613. Pubmed Central PMCID: 167287. Epub 1995/01/01. eng.

[104] Stewart P, Kersten P, Vanden Wymelenberg A, Gaskell J, Cullen D. Lignin peroxidase gene family of Phanerochaete chrysosporium: complex regulation by carbon 
and nitrogen limitation and identification of a second dimorphic chromosome. J Bacteriol. 1992 Aug;174(15):5036-42. PubMed PMID: 1629160. Pubmed Central PMCID: 206318. Epub 1992/08/01. eng.

[105] Giardina P, Faraco V, Pezzella C, Piscitelli A, Vanhulle S, Sannia G. Laccases: a never-ending story. Cell Mol Life Sci. 2010 Feb;67(3):369-85. PubMed PMID: 19844659. Epub 2009/10/22. eng.

[106] Soden DM, Dobson ADW. Differential regulation of laccase gene expression in Pleurotus sajor-caju. Microbiol-Sgm. 2001 Jul;147:1755-63. PubMed PMID: ISI: 000169732100005. English.

[107] Scheel T, Hofer M, Ludwig S, Holker U. Differential expression of manganese peroxidase and laccase in white-rot fungi in the presence of manganese or aromatic compounds. Appl Microbiol Biotechnol. 2000 Nov;54(5):686-91. PubMed PMID: 11131396. Epub 2000/12/29. eng.

[108] van Peij NN, Visser J, de Graaff LH. Isolation and analysis of xlnR, encoding a transcriptional activator co-ordinating xylanolytic expression in Aspergillus niger. Mol Microbiol. 1998 Jan;27(1):131-42. PubMed PMID: 9466262. Epub 1998/02/18. eng.

[109] van Peij NN, Gielkens MM, de Vries RP, Visser J, de Graaff LH. The transcriptional activator $X \ln R$ regulates both xylanolytic and endoglucanase gene expression in Aspergillus niger. Appl Environ Microbiol. 1998 Oct;64(10):3615-9. PubMed PMID: 9758775. Pubmed Central PMCID: 106473. Epub 1998/10/06. eng.

[110] Hasper AA, Visser J, de Graaff LH. The Aspergillus niger transcriptional activator $\mathrm{X} \operatorname{lnR}$, which is involved in the degradation of the polysaccharides xylan and cellulose, also regulates D-xylose reductase gene expression. Mol Microbiol. 2000 Apr; 36(1):193-200. PubMed PMID: 10760176. Epub 2000/04/12. eng.

[111] Gielkens MM, Dekkers E, Visser J, de Graaff LH. Two cellobiohydrolase-encoding genes from Aspergillus niger require D-xylose and the xylanolytic transcriptional activator XlnR for their expression. Appl Environ Microbiol. 1999 Oct;65(10):4340-5. PubMed PMID: 10508057. Pubmed Central PMCID: 91575. Epub 1999/10/03. eng.

[112] Marui J, Tanaka A, Mimura S, de Graaff LH, Visser J, Kitamoto N, et al. A transcriptional activator, AoXlnR, controls the expression of genes encoding xylanolytic enzymes in Aspergillus oryzae. Fungal Genet Biol. 2002 Mar;35(2):157-69. PubMed PMID: 11848678. Epub 2002/02/19. eng.

[113] Finn RD, Mistry J, Schuster-Bockler B, Griffiths-Jones S, Hollich V, Lassmann T, et al. Pfam: clans, web tools and services. Nucleic Acids Res. 2006 Jan 1;34(Database issue):D247-51. PubMed PMID: 16381856. Pubmed Central PMCID: 1347511. Epub 2005/12/31. eng.

[114] Hasper AA, Trindade LM, van der Veen D, van Ooyen AJ, de Graaff LH. Functional analysis of the transcriptional activator XlnR from Aspergillus niger. Microbiology. 2004 May;150(Pt 5):1367-75. PubMed PMID: 15133098. Epub 2004/05/11. eng. 
[115] Omony J, de Graaff LH, van Straten G, van Boxtel AJ. Modeling and analysis of the dynamic behavior of the XlnR regulon in Aspergillus niger. BMC Syst Biol. 2011;5 Suppl 1:S14. PubMed PMID: 21689473. Pubmed Central PMCID: 3121114. Epub 2011/06/28. eng.

[116] Omony J, Mach-Aigner AR, de Graaff LH, van Straten G, van Boxtel AJ. Evaluation of Design Strategies for Time Course Experiments in Genetic Networks: Case Study of the XlnR Regulon in Aspergillus niger. IEEE/ACM Trans Comput Biol Bioinform. 2012 Apr 16. PubMed PMID: 22529332. Epub 2012/04/25. Eng.

[117] Saloheimo A, Aro N, Ilmen M, Penttila M. Isolation of the ace1 gene encoding a Cys(2)-His(2) transcription factor involved in regulation of activity of the cellulase promoter cbh1 of Trichoderma reesei. J Biol Chem. 2000 Feb 25;275(8):5817-25. PubMed PMID: 10681571. Epub 2000/02/22. eng.

[118] Aro N, Ilme ' n, M., Saloheimo, A. and Penttila , M. ACEI is a repressor of cellulase and xylanase genes in Trichoderma reesei. Appl Environ Microbiol. 2002;69:56-65..

[119] Aro N, Saloheimo A, Ilmen M, Penttila M. ACEII, a novel transcriptional activator involved in regulation of cellulase and xylanase genes of Trichoderma reesei. Journal of Biological Chemistry. 2001 Jun 29;276(26):24309-14. PubMed PMID: ISI: 000169531100142. English.

[120] Witteveen CFB, Busink R, Vandevondervoort P, Dijkema C, Swart K, Visser J. L-Arabinose and D-Xylose Catabolism in Aspergillus-Niger. Journal of General Microbiology. 1989 Aug;135:2163-71. PubMed PMID: ISI:A1989AL64700004. English.

[121] vanKuyk PA, de Groot MJ, Ruijter GJ, de Vries RP, Visser J. The Aspergillus niger Dxylulose kinase gene is co-expressed with genes encoding arabinan degrading enzymes, and is essential for growth on D-xylose and L-arabinose. Eur J Biochem. 2001 Oct;268(20):5414-23. PubMed PMID: 11606204. Epub 2001/10/19. eng.

[122] Seiboth B, Hartl L, Pail M, Kubicek CP. D-xylose metabolism in Hypocrea jecorina: loss of the xylitol dehydrogenase step can be partially compensated for by lad1-encoded L-arabinitol-4-dehydrogenase. Eukaryot Cell. 2003 Oct;2(5):867-75. PubMed PMID: 14555469. Pubmed Central PMCID: 219359. Epub 2003/10/14. eng.

[123] de Groot MJ vdDC, Wosten HAB, Levisson M, vanKuyk PA, Ruijter GJG, de Vries RP. Regulation of pentose catabolic pathway genes of Aspergillus niger. Food Technol Biotechnol 2007;45:134-8.

[124] Flipphi MJ, Visser J, van der Veen P, de Graaff LH. Arabinase gene expression in Aspergillus niger: indications for coordinated regulation. Microbiology. 1994 Oct;140 ( Pt 10):2673-82. PubMed PMID: 8000538. Epub 1994/10/01. eng.

[125] Battaglia E, Hansen SF, Leendertse A, Madrid S, Mulder H, Nikolaev I, et al. Regulation of pentose utilisation by AraR, but not XlnR, differs in Aspergillus nidulans and Aspergillus niger. Appl Microbiol Biotechnol. 2011 Jul;91(2):387-97. PubMed PMID: 21484208. Pubmed Central PMCID: 3125510. Epub 2011/04/13. eng. 
[126] de Groot MJ, Prathumpai W, Visser J, Ruijter GJ. Metabolic control analysis of Aspergillus niger L-arabinose catabolism. Biotechnol Prog. 2005 Nov-Dec;21(6):1610-6. PubMed PMID: 16321042. Epub 2005/12/03. eng.

[127] Tani S, Kanamasa S, Sumitani J, Arai M, Kawaguchi T. XlnR-independent signaling pathway regulates both cellulase and xylanase genes in response to cellobiose in Aspergillus aculeatus. Curr Genet. 2012 Apr;58(2):93-104. PubMed PMID: 22371227. Epub 2012/03/01. eng.

[128] Endo Y, Yokoyama M, Morimoto M, Shirai K, Chikamatsu G, Kato N, et al. Novel promoter sequence required for inductive expression of the Aspergillus nidulans endoglucanase gene eglA. Biosci Biotechnol Biochem. 2008 Feb;72(2):312-20. PubMed PMID: 18256482. Epub 2008/02/08. eng.

[129] Petersen KL, Lehmbeck J, Christensen T. A new transcriptional activator for amylase genes in Aspergillus. Mol Gen Genet. 1999 Dec;262(4-5):668-76. PubMed PMID: 10628849. Epub 2000/01/11. eng.

[130] vanKuyk PA, Benen JA, Wosten HA, Visser J, de Vries RP. A broader role for AmyR in Aspergillus niger: regulation of the utilisation of D-glucose or D-galactose containing oligo- and polysaccharides. Appl Microbiol Biotechnol. 2012 Jan;93(1):285-93. PubMed PMID: 21874276. Pubmed Central PMCID: 3251782. Epub 2011/08/30. eng.

[131] Carlsen M, Nielsen J. Influence of carbon source on alpha-amylase production by Aspergillus oryzae. Appl Microbiol Biotechnol. 2001 Oct;57(3):346-9. PubMed PMID: 11759683. Epub 2002/01/05. eng.

[132] Davis RH, Perkins DD. Timeline: Neurospora: a model of model microbes. Nat Rev Genet. 2002 May;3(5):397-403. PubMed PMID: 11988765. Epub 2002/05/04. eng.

[133] Turner BC, Perkins DD, Fairfield A. Neurospora from natural populations: a global study. Fungal Genet Biol. 2001 Mar;32(2):67-92. PubMed PMID: 11352529. Epub 2001/05/16. eng.

[134] Tian C, Beeson WT, Iavarone AT, Sun J, Marletta MA, Cate JH, et al. Systems analysis of plant cell wall degradation by the model filamentous fungus Neurospora crassa. Proc Natl Acad Sci U S A. 2009 Dec 29;106(52):22157-62. PubMed PMID: 20018766. Pubmed Central PMCID: 2794032. Epub 2009/12/19. eng.

[135] Sun J, Tian C, Diamond S, Glass NL. Deciphering transcriptional regulatory mechanisms associated with hemicellulose degradation in Neurospora crassa. Eukaryot Cell. 2012 Apr;11(4):482-93. PubMed PMID: 22345350. Pubmed Central PMCID: 3318299. Epub 2012/02/22. eng.

[136] Coradetti ST, Craig JP, Xiong Y, Shock T, Tian C, Glass NL. Conserved and essential transcription factors for cellulase gene expression in ascomycete fungi. Proc Natl Acad Sci U S A. 2012 May 8;109(19):7397-402. PubMed PMID: 22532664. Pubmed Central PMCID: 3358856. Epub 2012/04/26. eng. 
[137] Bailey CaA, H.N. Jr. Carbon catabolite repression in Aspergillus nidulans. Eur J Biochem. 1975;21:573- 7 .

[138] Felenbock B, Flipphi, M., Nikolaev, I. Ethanol catabolism in Aspergillus nidulans: a model system for studying gene regulation. Prog Nucleic Acid Res Mol Biol. 2001;69:149-204.

[139] Flipphi M, Mathieu, M., Cirpus, I., Panozzo, C., Felenbock, B. Regulation of the aldehyde dehydrogenase gene (aldA) and its role in the control of the coinducer level necessary for the induction of the ethanol utilization pathway in Aspergillus nidulans. Journal of Biological Chemistry. 2001;276:6950-8.

[140] Flipphi M, Kocialkowska J, Felenbok B. Characteristics of physiological inducers of the ethanol utilization (alc) pathway in Aspergillus nidulans. Biochem J. 2002 May 15;364(Pt 1):25-31. PubMed PMID: 11988072. Pubmed Central PMCID: 1222541. Epub 2002/05/04. eng.

[141] Flipphi MaF, B. The onset of carbon catabolic repression and interplay between specific induction and carbon catabolite repression in Aspergillus nidulans. The Mycota III. 2nd ed. Berlin: Springer-Verlag; 2004. p. 403-20.

[142] Panozzo C, Cornillot E, Felenbok B. The CreA repressor is the sole DNA-binding protein responsible for carbon catabolite repression of the alcA gene in Aspergillus nidulans via its binding to a couple of specific sites. J Biol Chem. 1998 Mar 13;273(11): 6367-72. PubMed PMID: 9497366. Epub 1998/04/16. eng.

[143] Mathieu M, Fillinger S, Felenbok B. In vivo studies of upstream regulatory cis-acting elements of the alcR gene encoding the transactivator of the ethanol regulon in Aspergillus nidulans. Mol Microbiol. 2000 Apr;36(1):123-31. PubMed PMID: 10760169. Epub 2000/04/12. eng.

[144] Orejas M, MacCabe AP, Perez Gonzalez JA, Kumar S, Ramon D. Carbon catabolite repression of the Aspergillus nidulans xlnA gene. Mol Microbiol. 1999 Jan;31(1): 177-84. PubMed PMID: 9987120. Epub 1999/02/13. eng.

[145] Orejas M, MacCabe AP, Perez-Gonzalez JA, Kumar S, Ramon D. The wide-domain carbon catabolite repressor CreA indirectly controls expression of the Aspergillus nidulans $x \operatorname{lnB}$ gene, encoding the acidic endo-beta-(1,4)-xylanase $X(24)$. J Bacteriol. 2001 Mar;183(5):1517-23. PubMed PMID: 11160081. Pubmed Central PMCID: 95035. Epub 2001/02/13. eng.

[146] Tamayo EN, Villanueva A, Hasper AA, de Graaff LH, Ramon D, Orejas M. CreA mediates repression of the regulatory gene $x \ln R$ which controls the production of xylanolytic enzymes in Aspergillus nidulans. Fungal Genet Biol. 2008 Jun;45(6):984-93. PubMed PMID: 18420433. Epub 2008/04/19. eng.

[147] Bai C, Sen P, Hofmann K, Ma L, Goebl M, Harper JW, et al. SKP1 connects cell cycle regulators to the ubiquitin proteolysis machinery through a novel motif, the F-box. Cell. 1996 Jul 26;86(2):263-74. PubMed PMID: 8706131. Epub 1996/07/26. eng. 
[148] Craig KL, Tyers M. The F-box: a new motif for ubiquitin dependent proteolysis in cell cycle regulation and signal transduction. Prog Biophys Mol Biol. 1999;72(3): 299-328. PubMed PMID: 10581972. Epub 1999/12/03. eng.

[149] Colabardini AC, Humanes AC, Gouvea PF, Savoldi M, Goldman MH, Kress MR, et al. Molecular characterization of the Aspergillus nidulans fbxA encoding an F-box protein involved in xylanase induction. Fungal Genet Biol. 2012 Feb;49(2):130-40. PubMed PMID: 22142781. Epub 2011/12/07. eng.

[150] Hasunuma T, Kondo A. Development of yeast cell factories for consolidated bioprocessing of lignocellulose to bioethanol through cell surface engineering. Biotechnol Adv. 2011 Nov 4. PubMed PMID: 22085593. Epub 2011/11/17. Eng.

[151] Cherry JM, Hong EL, Amundsen C, Balakrishnan R, Binkley G, Chan ET, et al. Saccharomyces Genome Database: the genomics resource of budding yeast. Nucleic Acids Res. 2012 Jan;40(Database issue):D700-5. PubMed PMID: 22110037. Pubmed Central PMCID: 3245034. Epub 2011/11/24. eng.

[152] Krivoruchko A, Siewers V, Nielsen J. Opportunities for yeast metabolic engineering: Lessons from synthetic biology. Biotechnol J. 2011 Mar;6(3):262-76. PubMed PMID: 21328545. Epub 2011/02/18. eng.

[153] Kondo A, Ishii J, Hara KY, Hasunuma T, Matsuda F. Development of microbial cell factories for bio-refinery through synthetic bioengineering. J Biotechnol. 2012 Jun 19. PubMed PMID: 22728424. Epub 2012/06/26. Eng.

[154] Nielsen J, Jewett MC. Impact of systems biology on metabolic engineering of Saccharomyces cerevisiae. FEMS Yeast Res. 2008 Feb;8(1):122-31. PubMed PMID: 17727659. Epub 2007/08/31. eng.

[155] Matsushika A, Inoue H, Kodaki T, Sawayama S. Ethanol production from xylose in engineered Saccharomyces cerevisiae strains: current state and perspectives. Appl Microbiol Biotechnol. 2009 Aug;84(1):37-53. PubMed PMID: 19572128. Epub 2009/07/03. eng.

[156] Van Vleet JH, Jeffries TW. Yeast metabolic engineering for hemicellulosic ethanol production. Curr Opin Biotechnol. 2009 Jun;20(3):300-6. PubMed PMID: 19545992. Epub 2009/06/24. eng.

[157] Lynd LR, van Zyl WH, McBride JE, Laser M. Consolidated bioprocessing of cellulosic biomass: an update. Curr Opin Biotechnol. 2005 Oct;16(5):577-83. PubMed PMID: 16154338. Epub 2005/09/13. eng.

[158] Lynd LR, Elander RT, Wyman CE. Likely features and costs of mature biomass ethanol technology. Appl Biochem Biotech. 1996 Spr;57-8:741-61. PubMed PMID: ISI:A1996UL85700075. English.

[159] Wargacki AJ, Leonard E, Win MN, Regitsky DD, Santos CNS, Kim PB, et al. An Engineered Microbial Platform for Direct Biofuel Production from Brown Macroalgae. Science. 2012 Jan 20;335(6066):308-13. PubMed PMID: ISI:000299273400040. English. 
[160] Gibson DG, Glass JI, Lartigue C, Noskov VN, Chuang RY, Algire MA, et al. Creation of a Bacterial Cell Controlled by a Chemically Synthesized Genome. Science. $2010 \mathrm{Jul}$ 2;329(5987):52-6. PubMed PMID: ISI:000279402700028. English.

[161] Itaya M, Tsuge K. Construction and manipulation of giant DNA by a genome vector. Methods Enzymol. 2011;498:427-47. PubMed PMID: 21601689. Epub 2011/05/24. eng.

[162] Kaneko S, Itaya M. Designed horizontal transfer of stable giant DNA released from Escherichia coli. J Biochem. 2010 Jun;147(6):819-22. PubMed PMID: 20145021. Epub 2010/02/11. eng.

[163] Dymond JS, Richardson SM, Coombes CE, Babatz T, Muller H, Annaluru N, et al. Synthetic chromosome arms function in yeast and generate phenotypic diversity by design. Nature. 2011 Sep 22;477(7365):471-6. PubMed PMID: 21918511. Epub 2011/09/16. eng. 
